WISSENSCHAFTSZENTRUM BERLIN FÜR SOZIALFORSCHUNG

SOCIAL SCIENCE RESEARCH CENTER BERLIN

\author{
Klaus Gugler \\ Dennis C. Mueller \\ B. Burçin Yurtoglu
}

\title{
The Determinants of Merger Waves
}

University of Vienna

SP || $2006-01$

January 2006

ISSN Nr. $0722-6748$

Research Area

Markets and Politics

Research Unit

Competitiveness and Industrial Change
Forschungsschwerpunkt

Märkte und Politik

Abteilung

Wettbewerbsfähigkeit und industrieller Wandel 
Zitierweise/Citation:

Klaus Gugler, Dennis C. Mueller and B. Burçin Yurtoglu, The Determinants of Merger Waves, Discussion Paper SP I| 2006 - 01, Wissenschaftszentrum Berlin, 2006.

Wissenschaftszentrum Berlin für Sozialforschung gGmbH, Reichpietschufer 50, 10785 Berlin, Germany, Tel. (030) 25491 - 0 Internet: www.wz-berlin.de 


\section{ABSTRACT}

\section{The Determinants of Merger Waves*}

by Klaus Gugler, Dennis C. Mueller and B. Burçin Yurtoglu

One of the most conspicuous features of mergers is that they come in waves, and that these waves are correlated with increases in share prices and price/earnings ratios. We test four hypotheses that have been advanced to explain merger waves: the industry shocks, q-, overvaluation and managerial discretion hypotheses. The first two are neoclassical in that they assume that managers maximize profits, mergers create wealth, and the capital market is efficient. The last two, behavioral hypotheses relax these assumptions in different ways. We test the four hypotheses by estimating models of the amounts of assets acquired by firms, models that identify the characteristics of targets, and estimates of the returns to acquirers' shareholders. Although some support is found for each of the four hypotheses, most of the evidence favors the two behavioral hypotheses.

Keywords: Mergers waves, managerial discretion, overvaluation

JEL Classification: G34, L2

The research in this article was supported in part by the Austrian National Bank's Jubiläumsfond, Project 8861. We wish to thank participants in the workshop on corporate governance in Vienna in December, 2003 for helpful comments, and especially in this regard John Cable. Klaus Gugler also thanks the Wissenschaftszentrum Berlin für Sozialforschung(WZB) for its hospitality and its partial financial support. 


\section{Die Determinanten von Fusionswellen}

Es ist eines der auffallendsten Merkmale von Unternehmenszusammenschlüssen, dass sie in Wellen stattfinden und dass diese Wellen mit dem Anstieg der Aktienkurse und des Preis/ Ertragsverhältnisses zusammen hängen. Wir untersuchen vier Hypothesen, die als Erklärung von Unternehmenszusammenschlüssen genannt werden: die der Industrieschocks, die q-Hypothese, die Hypothese der Überbewertung und die Hypothesen des Ermessensspielraums von Managern. Die ersten zwei sind neoklassischer Natur insofern als sie davon ausgehen, dass Manager Gewinne maximieren, Unternehmenszusammenschlüsse Reichtum schaffen und der Kapitalmarkt effizient ist. Die zwei letzteren sind Verhaltenshypothesen, die die neoklassischen Annahmen (auf unterschiedliche Weise) lockern. Wir untersuchen die vier Hypothesen, indem wir Modellschätzungen der von Unternehmen akquirierten Aktien vornehmen. Dabei werden in den Modellen die Charakteristika der bei Zusammenschlüssen aufgekauften Unternehmen identifiziert und die Rendite für die Aktionäre des aufkaufenden Unternehmens geschätzt. Auch wenn alle vier Hypothesen in gewisser Hinsicht Bestätigung finden, untermauern die meisten Belege die zwei Verhaltenshypothesen. 
One of the most striking characteristics of mergers is that they come in bunches. This characteristic is readily apparent in Figure 1, where the number of mergers is plotted beginning in the 1880s. ${ }^{1}$ The second curve in Figure 1 is the Standard and Poor's (S\&P) price/earnings ratio $(\mathrm{P} / \mathrm{E})$. A close association between aggregate merger activity and the $\mathrm{S} \& \mathrm{P} \mathrm{P} / \mathrm{E}$ is apparent, and it can be regarded as the second major regularity in aggregate merger data. ${ }^{2}$ Any hypothesis that claims to explain merger waves must account for this relationship.

An enormous number of hypotheses have been advanced to explain why mergers take place. $^{3}$ These fall broadly into two categories: (1) neoclassical theories that assume that managers maximize profits or shareholder wealth and thus that mergers increase either market power or efficiency, or (2) non-neoclassical or behavioral theories that posit some other motivation for mergers and/or other consequences.

Most of the hypotheses have been advanced to explain specific kinds of mergers. Vertical mergers have been explained, for example, as attempts both to increase market power by increasing barriers to entry (Comanor, 1967), and to increase efficiency by reducing transaction costs (Williamson, 1975). We find many of these hypotheses to be plausible explanations for some mergers, but they do not offer convincing explanations for waves in aggregate merger activity. For example, a vertical merger between two firms possessing assets dedicated to transacting with each other can reduce transaction costs, but it is difficult to imagine why the conditions necessary to make such mergers profitable would appear across a sufficient number of industries at a particular point in time to generate a wave in aggregate merger activity, and why this point in time should correspond to a stock market rally.

We assume that mergers such as these are taking place all of the time. For a merger wave to occur some sorts of mergers must greatly increase in frequency at particular points in 
time. Our task is then to determine which hypotheses are likely to predict such variations in the frequency of mergers over time.

In this article we examine four hypotheses that have been put forward specifically as explanations of merger waves - the industry shocks hypothesis, the $q$-theory, and the overvaluation and managerial discretion hypotheses. The first two are neoclassical in that they assume (1) that managers maximize shareholders' wealth, (2) mergers are wealth creating, and (3) capital market efficiency. The other two may be classified as behavioral, because they drop the assumption of capital market efficiency and/or that managers maximize their shareholders' wealth.

Although the assumptions underlying the four hypotheses differ in these basic ways, there is some overlap in their predictions making it difficult to discriminate among them by comparing the results from each theory's implied model of the determinants of mergers. The theories differ in part, however, not only with respect to their predictions about the determinants of mergers, but also with respect to their predictions about (1) the determinants of tender offers versus friendly mergers, (2) the characteristics of target firms, and (3) the post-merger share performance of acquiring firms. To help discriminate among the four hypotheses, each of these additional sets of predictions is also examined.

The next four sections present the underlying logic of each hypothesis followed by a critique. These logical critiques are an important part of our effort to discriminate among the theories. The empirical evidence must carry less of a burden, if the underlying logic of a hypothesis is weak or inconsistent with other facts about mergers. Each critique is followed by a discussion of the existing evidence in support of the theory and our test of it. In Section V we discuss our data, while Sections VI-IX contain the results of the tests. Some conclusions are drawn in the final section. 


\section{The Industry Shocks Hypothesis}

\section{A. Underlying Logic}

Several studies have presented evidence of significant variations in merger activity across industries (Mitchell and Mullerin, 1996; Mullerin and Boone, 2000; Andrade, Mitchell and Stafford, 2001; and Harford, 2004). To go from waves within individual industries to a wave across the entire economy, several industries must enter a wave at the same time. Only Harford has claimed that this happens, and thus we focus on his arguments and evidence.

Harford puts forth his "neoclassical explanation of merger waves" as an alternative to one of the behavioral hypotheses discussed below. He argues that

...merger waves occur in response to specific industry shocks that require large scale reallocation of assets. However, these shocks are not enough. There must be sufficient capital liquidity to accommodate the asset reallocation. The increase in capital liquidity and reduction in financing constraints that is correlated with high asset values must be present for the shock to propagate a wave.... Thus, the explanation for merger waves is intuitive: they require both an economic motivation for transactions and relatively low transaction costs to generate the large volume of transactions. (Harford, 2004)

\section{B. Critique}

There are two ways to interpret the industry shocks hypothesis (hereafter ISH). (1) All industries are buffeted by shocks from time to time and once and awhile several industries receive shocks at the same time. When this event is accompanied by a macro-level expansion in liquidity, all of the industries receiving shocks enter into a merger wave producing a wave in the aggregate. It strikes us unlikely that these two events would occur simultaneously. Moreover, recalling the two curves in figure 1, it must be the case that there has been a clustering of industry shocks at the beginning of every stock market boom. This strikes us as a remarkable set of coincidences. 
(2) Industries are buffeted by shocks all of the time and at any particular point in time several industries have recently received shocks. When there is a macro-level expansion in liquidity, all of the industries recently receiving shocks enter into a merger wave producing a wave in the aggregate. Here we merely note that under this interpretation of the ISH the shocks hitting industries do not explain the merger wave, but only which industries enter into it. The wave itself is explained entirely by macroeconomic liquidity factors.

The argument that mergers are constrained by macroeconomic liquidity conditions is, however, problematic, given the neoclassical assumptions underlying the industry shocks hypothesis - managers maximize shareholder wealth, mergers are wealth enhancing, the capital market is efficient. To see the difficulty, consider two firms $A$ and $B$. $A$ has 100 shares outstanding with a price $\mathrm{P}_{\mathrm{A}}=1$, and thus a market value of $\mathrm{M}_{\mathrm{A}}=100 . B$ has 50 shares outstanding with a price $\mathrm{P}_{\mathrm{B}}=1$, and a market value of $\mathrm{M}_{\mathrm{B}}=50$. A merger between the two firms will produce a company $C$ with a market value of 180 . Firm $A$ announces that it plans to acquire $B$ by issuing $I$ shares of its own stock for all 50 of $B$ 's. The efficient capital market assumption implies that the share price of the new firm $C$ immediately rises upon the merger's announcement to reflect the new firm's true value, $180=\mathrm{P}_{\mathrm{C}}(100+\mathrm{I})$. The gain from the merger to the shareholders of $A$ is $P_{C} 100-100$, and the gain to the shareholders of $B$ is $\mathrm{P}_{\mathrm{C}} \mathrm{I}-50$. The assumption that the managers of $A$ and $B$ maximize their shareholders' wealth implies that an $I$ is agreed upon such that both gains are positive. The transaction costs of making such share exchanges should be independent of macroeconomic liquidity conditions. So long as $A$ and $B$ have shares outstanding, such exchanges will be mutually beneficial.

Acquiring firms are generally much larger than the companies they acquire, and very few mergers of any importance are undertaken by firms that do not have stock outstanding. The targets of acquisitions may, however, be small firms or divisions of firms that do not have shares outstanding. This does not change the logic of the above argument, however. A 
announces that it intends to acquire $B$ or a division of $B$, and that it will sell $I$ of its own shares to finance the purchase. The efficient capital market factors in both the sale of the shares and the acquisition of the assets and sets a new price for A's shares that allows it to undertake the transaction paying for the assets with the cash raised from the sale of its shares.

Here it should be noted that the fact that share prices and Tobin's qs are high during a stock market boom cannot be used to argue that financing mergers through share swaps is relatively cheap during stock market booms. Under the efficient capital market assumption

underlying the ISH, shares are always accurately (unbiasedly) priced. A firm with a $q$ of two is perceived by the market to have significantly better prospects than a firm with a $q$ of one. It costs the first firm's shareholders just as much in forgone wealth to issue $\$ 100$ of its shares as it does for the second. The notion that equity capital is a relatively cheap source of finance when $\mathrm{P} / \mathrm{E}$ ratios or $q \mathrm{~s}$ are above their long-run averages implicitly denies the efficiency of the capital market and feeds into the overvaluation and managerial discretion hypotheses.

\section{Testing the ISH}

\section{Determinants of mergers}

In Harford's tests of the ISH several measures of industry shocks plus a measure of macroeconomic credit conditions prove to be significant. Our tests of the four hypotheses employ firm-level data, and so we test the ISH in a different way. It is obvious from figure 1 that there is considerable time series variation in merger activity. The ISH claims that this is explained by time series variation in industry merger activity. Thus, knowing what industry a firm is in should contribute to the explanatory power of the equation. We assign each firm to one of the 48 industries used by Harford and create 48 industry dummies ${ }^{4}$. We then first determine how much variation in merger activity two-year time dummies alone can explain. We choose two-year intervals on the grounds that a surge in merger activity must be of at least two years duration to constitute a wave (Harford also identifies waves in two-year 
intervals). We then see how much additional explanatory power is obtained when the pure time dummies are replaced by time/industry-dummy interactions. This way of testing the ISH obviates the need to identify the shocks that led to merger waves in particular industries. Regardless of the cause of the industry wave, under the ISH knowledge of the industry a firm is in at a particular point in time should add explanatory power to simply knowing what the point in time is. This reasoning leads to the following test of the ISH as it pertains to the determinants of mergers.

ISH-DM. A set of industry-time dummies adds considerable explanatory power to an equation explaining merger activity over simply a set of time dummies.

The ISH also stresses the importance of macroeconomic liquidity constraints, which Harford measures by the spread between the commercial and industrial loan rate and the federal funds rate (hereafter C\&I). Although, as discussed above, the logic of this argument is problematic for the overwhelming majority of firms making acquisitions, we test whether C\&I contributes to the explanatory power of the model.

\section{Tender offers versus friendly mergers}

An important distinction in the two behavioral hypotheses is between tender offers and friendly mergers. A friendly merger is defined as one for which the terms of the transaction are agreed to by the managers of the two firms. In a tender offer, the acquirer's managers set the terms through a bid for the target's shares at a particular price. Under the ISH all mergers are expected to be profitable, thus both tender offers and friendly mergers should be profitable. Once a firm's managers decide to acquire another firm, they have a choice between a friendly merger and a takeover. If the price that the target's managers are willing to sell for is less than what the acquirers' managers think they would have to bid in a tender offer, they will choose the friendly merger. If the target's managers demand a price 
greater than what the acquirers' managers expect to have to bid in a tender offer, they will favor the tender offer. The choice between the two should depend entirely on their relative transaction costs. This leads to the following tests under the ISH

ISH-TO. The variables used to explain acquisitions should have the same coefficients for tender offers and friendly mergers.

\section{Characteristics of target firms}

It seems to us that the kinds of shocks posited by the proponents of the ISH technological innovations, deregulation - would be more likely to lead to horizontal than to conglomerate mergers, but its proponents have not limited their tests to horizontal mergers, and thus we test it for all forms of mergers.

\section{Share performance of acquiring firms}

The assumption of capital market efficiency implies that all wealth gains from a merger are registered in share price movements at its announcement. Over longer time spans following a merger its share performance should be indistinguishable from non-merging firms. The assumptions that managers maximize their shareholders' wealth, and that mergers are wealth creating imply that acquiring firms' shares exhibit positive abnormal returns at acquisition announcements. Following the reasoning underlying ISH-TO, this prediction should hold for both tender offers and friendly mergers.

ISH-SP1. Acquirers in both friendly mergers and tender offers make significant positive abnormal returns on their shares at the acquisition announcements, and normal returns over longer post-merger windows.

Some industries experience merger waves when there is no wave in aggregate activity. Presumably these too are caused by industry shocks, and thus the ISH must predict 
that mergers during both waves in aggregate merger activity and outside of these waves meet the neoclassical assumptions underlying the hypothesis.

ISH-SP2. The share performance of acquirers is consistent with ISH-SP1 for mergers taking place during both wave and non-wave years.

\section{The q-Theory of Mergers}

\section{A. Underlying Logic}

Under the q-theory of investment, when a firm's return on its capital stock exceeds its cost of capital, $q>1$, and it expands its capital stock. A straightforward application of the theory to mergers would imply that firms with $q \mathrm{~s}>1$ can profitably expand by acquiring assets either in the form of capital investment or mergers. ${ }^{5}$ Since $q$ measures returns on a firm's existing assets, it would seem that a direct application of the $q$-theory to mergers would only allow one to explain horizontal mergers, i.e., additions to existing capital stock. Since less than half of all mergers are horizontal, this implication of the $q$-theory leaves over half of all mergers unaccounted for. ${ }^{6}$

An alternative interpretation of the $q$-theory would be that a $q>1$ does not necessarily imply that a firm can profitably expand by acquiring more assets in its base industry, but that the firm is well managed and could profitably expand in any direction. ${ }^{7}$ Tobin's $q$ under this interpretation is not a measure of the quality of a firm's assets, but of its management.

Jovanovic and Rousseau (2002) (hereafter J\&R) are the only ones to have applied the $q$-theory to mergers and to claim that it accounts for merger waves. They liken mergers to the purchase of used plant and equipment, and argue that the gap between the qs of potential acquiring firms and targets increases at particular points - as during a stock market boom - 
and this widening difference leads managers to favor purchasing other firms over used capital equipment thus creating a merger wave.

\section{B. Critique}

When a firm expands it has three options: purchase new plant and equipment, purchase used plant and equipment, or acquire another company. J\&R assume that a firm limits its options to the latter two. But this is unlikely to be optimal. As share prices rise during a stock market rally, the cost of acquiring capital by buying other firms rises relative to that for new and used capital. Table 1 reports the mean $q$ s for acquirers and targets in tender offers and friendly mergers over our sample period. ${ }^{8}$ The mean $q$ s for targets of friendly mergers exceed 1.0 in all but two years and rise to as high as 1.5 during the 1995 2000 merger wave. Since the $q$ for new or used plant and equipment equals 1.0 by definition, these forms of asset acquisitions must dominate mergers, and mergers must become relatively less attractive during a merger wave when stock prices are rising. This point is reinforced when one takes into account that acquiring firms must pay an additional premium over the market price of a company to acquire it. Thus, if one replaces a target's $q$ prior to an acquisition (we use the end of the previous year to measure this q), with the value actually paid for the target (deal value), the implied cost of asset acquisitions through mergers rises considerably. In several years acquirers paid on average more than double the values of the targets' assets. A similar but smaller increase is apparent for the targets of tender offers. ${ }^{9}$ The argument that merger waves occur during stock market booms, because buying other companies becomes relatively cheaper than purchasing assets in new or used capital markets is difficult to sustain in face of the evidence in table 1. 


\section{Testing the QH}

$\mathrm{J} \& \mathrm{R}$ test their $q$-theory of mergers by regressing the assets acquired in year $t$ by firm $i$ on $\left(q_{\mathrm{it}-1}-q_{\mathrm{Tt}-1}\right)$, where $q_{\mathrm{it}-1}$ is Tobin's $q$ for firm $i$ in period $t-1$, and $q_{\mathrm{Tt}-1}$ is the mean Tobin's $q$ for all target firms (i.e., the companies actually acquired) in period $t-1$. Defining the total amount of assets acquired through mergers in year $t$ as $M_{i t}$, we obtain

QH-DM1. $\mathrm{M}_{\mathrm{t}}$ is positively related to $\left(q_{\mathrm{it}-1}-q_{\mathrm{Tt}-1}\right)$.

A further implication of QH-DM1 is

QH-DM2. When $q_{\mathrm{it}-1}$ and $q_{\mathrm{Tt}-1}$ are entered separately in the $M_{\text {it }}$ equation, $q_{\mathrm{it}-1}$ has a positive coefficient and $q_{\mathrm{Tt}-1}$ a negative coefficient equal in absolute size to that of $q_{\mathrm{it}-1}$.

Since the QH shares the neoclassical assumptions of the ISH, it makes the same predictions with respect to tender offers versus friendly mergers, and share performance, and these hypotheses are not repeated here. Its prediction with respect to the characteristics of the targets is subsumed in QH-DM2.

\section{The Overvalued Shares Hypothesis}

\section{A. Underlying Logic}

In their theory, Shleifer and Vishny (2001) (hereafter S\&V) retain the assumption that managers maximize shareholders' wealth (at least as far as the acquiring firms are concerned), but relax the assumptions that mergers create wealth and of capital market efficiency. Some firms' share prices become overvalued during stock market booms. Their managers know their shares are overvalued, and wish to protect their shareholders from the wealth loss that will come when the market lowers its estimates to their warranted levels. They accomplish this by exchanging their overvalued shares for the real assets of another 
company, which the market presumably correctly prices. Targets' managers are assumed to have short time horizons, so they too gain by "cashing in" their stakes in their firms at favorable terms. Although mergers are not assumed to possess any wealth-creating synergies, under the overvaluation hypothesis (hereafter OVH) they appear to be win-win events, since both the acquiring firm's shareholders and the target's managers benefit from the mergers. ${ }^{10}$

\section{B. Critique}

S\&V's OVH suffers from a similar difficulty to that of J\&R's $q$-theory. Managers of acquiring firms are assumed to protect their shareholders from forthcoming wealth losses following the market's reevaluation of their shares. Such protection can be afforded by exchanging the overvalued shares for any assets that are correctly priced by the market. Since all share prices tend to rise during stock market booms, any firm that they buy is also likely to be overvalued, although not perhaps to the extent that they are. When one adds in the merger premia, buying companies during stock market booms must be rather expensive relative to other assets (see again figures in Table 1). An obvious alternative would be to issue shares to buy back one's own debt. The debt of other firms is another possibility, as is real estate, works of art, and any other real assets whose prices are not inflated during a stock market boom, and do not require premia of 20-30 percent or more to close the deal.

\section{Testing the $\mathrm{OVH}$}

\section{Determinants of mergers}

To test the OVH we need to measure the overvaluation for each firm. Here, we encounter a methodological difficulty. If we can identify firms that are overvalued, so too presumably can the capital market and the firms cease to be overvalued. This conundrum notwithstanding, several studies have found support for the OVH using various measures of 
overvaluation (Verter, 2002; Ang and Cheng, 2003; Dong, Hirshleifer, Richardson and Teoh, 2003; and Rhodes-Kropf, Robinson and Viswanathan, 2003, hereafter RKRV). These measures typically involve the ratio of market to book value of equity or its reciprocal. These ratios tend to be highly correlated with Tobin's $q$, the ratio of a firm's market value to the replacement value of its assets. Thus, there is some difficulty discriminating between the $\mathrm{QH}$ and $\mathrm{OVH}$, since the key variables in each are highly correlated. The logical underpinnings of each hypothesis as well as the additional tests also must be examined.

We measure overvaluation in a way that is similar to what others have done, but is easier to conceptualize and interpret. The market value of a firm $i$ can be written as the present value of its profit stream from now to infinity, where $\pi_{\mathrm{it}}$ is $i$ 's profits in period $t$, and $k_{i}$ is its cost of capital.

$$
V_{i 0}=\sum_{t=0}^{\infty} \frac{\pi_{i t}}{\left(1+k_{i}\right)^{t}}
$$

Assuming an average rate of growth of $g_{i}$ from now to infinity, (1) becomes

$$
V_{i 0}=\sum_{t=0}^{\infty} \frac{\pi_{i 0}\left(1+g_{i}\right)^{t}}{\left(1+k_{i}\right)^{t}}=\frac{\pi_{i o}}{k_{i}-g_{i}}
$$

if $k_{i}>g_{i}$. We assume that all firms in an industry have the same costs of capital and expected growth rates, and estimate $1 /\left(k_{i}-g_{i}\right)$ for a typical firm by regressing the market values of all firms in the industry on their profits for a period of time when, based on the aggregate price/earnings ratio for the $\mathrm{S} \& \mathrm{P}$ index, shares in aggregate do not appear to be overpriced. Call this estimate of $1 /\left(k_{i}-g_{i}\right), \alpha^{11}$. Using this $\alpha$ we predict firm i's market value in year $t$ as

$$
\mathrm{V}_{i t}^{\mathbf{L}}=d \pi_{i t}
$$

We then create a measure of a firm's overvaluation in any year, $O_{i t}$, as 


$$
O_{i t}=V_{i t}-\mathbf{k}_{i t}^{\mathbf{I}}
$$

With this measure of overvaluation we test

OVH-DM1. The assets acquired through mergers are positively related to $O_{i t}$.

If managers perceive their firm to be overvalued by, say $30 \%$, they have the same incentive to exchange these shares for correctly valued real or financial assets regardless of whether the stock market is at a normal level, depressed, or in a boom. The logic of the OVH implies that the same relationship between firm overvaluation and merger activity should hold at all points in time. What drives merger waves during stock market booms is that many more firms become overvalued. This further implication of the theory can be tested by decomposing $O_{i t}$ into two components, $O_{t}$, the mean level of overvaluation across the entire sample, and $d O_{i t}$, the deviation of firm $i$ 's overvaluation from this sample mean, $d O_{i t}=O_{i t}$ $O_{t}$. If one replaces $O_{i t}$ in the equation explaining merger activity with $d O_{i t}$ and $O_{t}$, both variables should have the same coefficient, if all that matters for mergers is the extent of overvaluation of the acquiring firms.

OVH-DM2. The assets acquired through mergers are positively related to $d O_{i t}$ and $O_{t}$, and both variables have identical coefficients.

\section{Tender offers versus friendly mergers}

Under the OVH, the targets' managers are willing partners in the mergers. Managers of targets in hostile takeovers are virtually never willing partners in the transactions. Although all tender offers are not hostile takeovers, they appear to be a less friendly way to acquire another company than through a mutual agreement among the two companies' managers. ${ }^{12}$ Thus, the OVH seems more plausible for friendly mergers than tender offers.

OVH-TO. The OVH is better supported for friendly mergers than for tender offers. 


\section{Characteristics of targets}

Under the $\mathrm{OVH}$, managers of targets wish to cash in their stakes in their companies. The incentive to cash in should be greater, the larger a stake is. This implication of the OVH is tested by constructing VS, the market value of the equity held by the insiders. ${ }^{13}$ It also seems reasonable that the managers are more eager to sell out, the more overvalued their shares are.

OVH-TC. The probability that firm $i$ is acquired in $t$ is a positive function of $V S_{i t}$ and $O_{i t}$.

\section{Share performance of acquiring firms}

At some point in time the capital market corrects its error, and the share price of an overvalued acquirer falls to its warranted level. The target's managers will not accept the acquirer's shares, however, if their price falls immediately upon the merger's announcement, because this would not allow them to "cash in." We thus have

OVH-SP1. The shares of acquiring firms earn large negative abnormal returns over long time spans following the mergers, but not immediately when they are announced.

The OVH assumes that the number of firms with overvalued shares increases during stock market booms and that this explains merger waves. Thus, it implies.

OVH-SP2. The post-merger performance of acquirers' shares is worse for mergers undertaken during merger waves. 


\section{The Managerial-Discretion Hypothesis}

\section{A. The Underlying Logic}

Robin Marris $(1964,1998)$ was the first to posit growth as an objective for managers, and Mueller (1969) applied the theory to explain the conglomerate merger wave of the late 1960s. Managers get utility from their firms' growth either because their incomes are tied to growth, or because they get "psychic income" from managing a larger firm. ${ }^{14}$ The constraint on managers' pursuit of growth is the threat of takeover, which is inversely related to $q$. Thus, managers' utility can be expressed as a function of the growth of their firms, $g$, and $q$, $U=U(g, q)$, where $\partial U / \partial g>0, \partial^{2} U / \partial g^{2}<0, \partial U / \partial q>0$, and $\partial^{2} U / \partial q^{2}<0 .{ }^{15}$

Defining $M$ as the amount of assets acquired through mergers, and setting $g=g(M)$, we can maximize $U(g, q)$ with respect to $M$ to determine the utility maximizing level of growth through mergers. This yields the following first order condition:

$$
(\partial U / \partial g)(\partial g / \partial M)=-(\partial U / \partial q)(\partial q / \partial M)
$$

Since $\partial U / \partial g>0, \partial g / \partial M>0$, and $\partial U / \partial q>0$, (5) cannot be satisfied if $\partial q / \partial M>0$. For any merger that increases $q$ no tradeoff between growth and security from takeovers exists. Growth-maximizing managers undertake all mergers that increase q. Their behavior differs from managers who maximize shareholder wealth only with respect to mergers that decrease q. In Figure 2 (A) we depict the relationship in eq. 5 for mergers that lower $q$. When no mergers of this type are undertaken, $q$ is at its maximum and the risk of takeover is minimized. When the relationship between $q$ and $M$ is such as to yield $-(\partial U / \partial q)(\partial q / \partial M)_{N}>0$, a utility-maximizing manager undertakes $\mathrm{M}_{\mathrm{N}}$ of value destroying mergers. 
To understand the link between the managerial discretion hypothesis (hereafter MDH) and merger waves, we must consider the psychology of the market during the stock market booms that accompany waves. As Galbraith (1961, p. 8) observed, an "indispensable element of fact" during stock market bubbles is that individuals "build a world of speculative make-believe. This is a world inhabited not by people who have to be persuaded to believe but by people who want an excuse to believe." These excuses to believe take the form of "theories" as to why share prices should rise to unprecedented levels, why the economy has entered a "new era" (Shiller, 2000, Ch. 5). Prominent among these are "theories" about wealth increases from mergers. Shiller gives an example from the stock market boom and merger wave at the beginning of the $20^{\text {th }}$ century. "The most prominent business news in the papers in recent years had been about the formation of numerous combinations, trusts, and mergers in a wide variety of businesses, stories such as the formation of U.S. Steel out of a number of smaller steel companies. Many stock market forecasters in 1901 saw these developments as momentous, and the term community of interest was commonly used to describe the new economy dominated by them" (Shiller, 2000, p. 101, italics in original). Shiller quotes an editorial from the New York Times from April 1901, which prophesizes that the U.S. Steel merger will avoid "much economic waste" and effect "various economies coincident to consolidation." The editorial also predicts similar benefits from mergers in railroads. Such optimism explains why U.S. Steel's share price soon soared to $\$ 55$ from the \$38 it was floated at in 1901. By 1903 it had plunged to \$9 (Economist, 1991, p. 11).

Thus, the willingness of investors to accept new news as good news during a stock market boom lowers the cost from announcing unprofitable mergers. Announcements of such mergers under normal conditions would result in large declines in the acquirers' share prices preventing their managers from undertaking the mergers. Announcements of the same mergers during a stock market boom lead to only modest falls in share price, or perhaps even 
increases. In a stock market boom, the relationship between $q$ and $M$ shifts from its normal level, say line $N$ in Figure 2 (B), to something like $B$. This change shifts $-(\partial U / \partial q)(\partial q / \partial M)$ to the right, as in Figure $2(\mathrm{~A})$. The firm acquires more assets through mergers, $\mathrm{M}_{\mathrm{B}}$, since $q$ does not drop by as much or perhaps even rises when a merger is announced.

This discussion of stock market psychology during booms sheds a different light on the ISH. To take advantage of the over-optimism in the market, the desire people have to believe share prices will rise, managers need to give them an "excuse to believe." Proclamations of synergies accompanying merger announcements may serve as such an excuse. If they do, other firms within an industry may decide to merge naming the same synergies, and a "theory" of industry-specific synergies is born. Twenty-five of the 34 industry waves that Harford (2004, Table 2) identifies occur during the 1995-2000 period, which we identify as the aggregate wave. One of these is in the insurance industry. The shock precipitating this wave according to Harford is "big is safer, leading to consolidation, especially in reinsurers." But certainly the advantages of size in insurance were well-known long before 1998. Did these gains really only become apparent in 1998, or did the optimism in the market at that time allow insurance companies to use size as a justification for mergers that would have met a cooler reception earlier? The wave in medical equipment had "Two motives: first, acquisitions in core areas to grow, then acquisitions outside core areas to offer broad products to increasingly consolidated customers (hospitals)." The first motive seems more consistent with the MDH than with a neoclassical theory of mergers, and the second resembles the justifications given for diversification mergers ever since the conglomerate merger wave of the ' $60 \mathrm{~s}$. Whether these and other reasons given by Harford for the industry waves represented real profit opportunities seized by managers, or merely their justifications 
offered to a gullible market cannot be determined ex ante, which is why we include additional evidence like the post-merger returns of acquiring companies. ${ }^{16}$

For a firm that overinvests, the marginal return on its investment is below its neoclassical cost of capital. Raising funds externally, therefore, will seem more expensive than using internal cash flows. Cash flows have, therefore, been a key variable for distinguishing between the MDH and the neoclassical theory in studies of the determinants of corporate investment and R\&D. ${ }^{17}$ Cash flows are thus included in our model, as an additional way to discriminate the $\mathrm{MDH}$ from the other hypotheses. ${ }^{18}$

\section{B. Critique}

The MDH is neoclassical in assuming maximizing behavior by the key agents managers of acquiring firms. Predicted changes in behavior are also caused by changes in the constraints - the threat of takeover falls during a stock market boom and cash flows increase. The MDH departs from most neoclassical economics, however, by assuming managers pursue growth and not shareholder wealth, and that stock market psychology influences managers' decisions. Although the MDH suffers from no logical inconsistencies, many will question its underlying assumptions. As always the proof is in the pudding, so we reserve further discussion of this issue until after we examine our results.

\section{Testing the MDH}

\section{Determinants of mergers}

The discussion in subsection A suggests including $q$ to measure the tightness of the takeover constraint, and cash flows to measure the funding constraints on managers. A high $q$ frees managers to finance unprofitable mergers by whatever means they choose, but a high $q$ should also make them particularly more willing to use their favorite source of finance cash flows. Thus, we also include an interaction term between $q$ and cash flow with a 
predicted positive sign. The higher $q$ is, the more discretion managers have to undertake unprofitable investments, and the larger is the predicted coefficient on cash flows. ${ }^{19}$

Holding $M$ constant, the larger the size of a potential acquirer, the less impact the acquisition has on its $q$. Thus, the curve relating $q$ to $M$ in Figure 2 should be flatter, the larger the size of the acquiring firm $(S)$ relative to the target, $M$. Assets acquired through mergers should vary positively with firm size.

To test the MDH, we need a variable to capture the degree of over optimism in the stock market. We have constructed such a variable in the previous section, the mean of the individual firm overvaluation measures, $O_{t}$. As this measure is a bit novel, we also experiment with a measure implied by Shiller's (2000) work - the S\&P P/E ratio $\left(\mathrm{P} / \mathrm{E}_{\mathrm{t}}\right)$. (We could subtract the average $\mathrm{P} / \mathrm{E}$ to measure over optimism, but subtracting a constant would not change the variable's statistical properties.) These considerations lead to

MDH-DM. $\frac{\partial M_{t}}{\partial C F_{t-1}}>0, \frac{\partial M_{t}}{\partial(P / E)_{t}}>0, \frac{\partial M_{t}}{\partial q_{t-1}}>0, \frac{\partial M_{t}}{\partial\left(q_{t-1} \cdot C F_{t-1}\right)}>0, \frac{\partial M_{t}}{\partial S_{t-1}}>0, \frac{\partial M_{t}}{\partial O_{t}}>0$

\section{Tender offers versus friendly mergers}

Tender offers are more likely to meet with resistance from target managers and thus involve higher transaction costs. Since acquiring firms' managers are only interested in growth under the MDH, they should not care which firms they acquire, and will thus favor friendly mergers because of their likely lower transaction costs. ${ }^{20}$

MDH-TO. The MDH-DM receives less support for tender offers, $T O_{i t}$, than for friendly mergers, $F M_{i t}$. 


\section{Characteristics of target firms}

All firms are potentially attractive candidates for acquisition by a growth-maximizing manager, and thus we formulate no separate hypothesis about the characteristics of targets under the MDH. We have argued, however, that the MDH should be more applicable to friendly mergers than to takeovers, and so in our empirical work we shall also test whether the characteristics of targets are different for these two sorts of acquisitions.

\section{Share performance of acquiring firms}

Mergers under the MDH are not assumed to be wealth creating. Since an acquiring firm pays a premium for a target's shares, its shareholders should suffer a wealth loss equal at minimum to the gain to the targets. ${ }^{21}$ On the other hand, the over optimism in the market that encourages managers to undertake wealth-destroying mergers should ensure that the acquirer's share price does not drop precipitously when the mergers are announced.

MDH-SP1. The shares of acquiring firms earn large negative abnormal returns over long time spans following the mergers, but not immediately when they are announced.

During stock market booms managers have more discretion to make-wealth destroying mergers, and the fraction of all mergers that fits the MDH increases leading to

MDH-SP2. The post-merger performance of acquirers' shares is worse for mergers undertaken during merger waves.

Thus the MDH makes the same predictions as the OVH with regard to share performance, although for different reasons. As explained above, we expect stronger support for the latter two hypotheses for friendly mergers than for tender offers. 


\section{Methodology and Data Description}

Our principal source of data is Global Mergers and Acquisitions database from Thompson Financial Securities Data. It contains merger and spin-off data from a variety of sources such as Reuters Textline, the Wall Street Journal, Dow Jones etc. The database covers all transactions valued at $\$ 1$ million or more. We define a merger or tender offer as a transaction where more than 50 percent of the target's equity is acquired. A tender offer is a formal offer of determined duration to acquire a company's shares made to its equity holders.

Table 1 presents the total numbers of acquisitions, friendly mergers and tender offers in our sample. The popularity of tender offers during the late 1980 s is readily apparent with their fraction of all acquisitions peaking at 26 percent in 1986. In reaction to the wave of hostile takeovers in the late 1980s, managers approached the legislatures in the states in which they were incorporated and demanded legislation that afforded them better protection against takeovers. Most readily complied, which helps explain the sharp relative decline in tender offers in the early 1990s (Roe, 1993).

The various hypotheses lead to predictions regarding the signs on the relevant variables, but in most cases do not predict the functional form of the relationship. We experimented with polynomials up to the third order, but report results for the higher order terms, only when they are significant.

Our models might be estimated twice, once as a probit regression to determine the probability that a company undertakes an acquisition, and a second time as a Tobit regression to take into account differences in the sizes of the targets. Both probit and Tobit regressions were estimated, but only the Tobit results are reported, because they differ from the probit results only with respect to the sizes of the coefficients on the different variables. That is to say, the same variables that explain whether or not a firm undertakes a merger in a particular 
year explain the amount of assets acquired. The close similarity between the results for the probit and Tobit estimations also implies that there was little to be gained from adopting Heckman's (1976) two-stage estimation procedure for censored data.

Summary statistics for our data are presented in Table 2a. $M_{i t}$ is the total consideration paid by the acquirer $i$ divided by its total assets in year $t .^{22}$ Tobin's $q$ is a firm's market value divided by its total assets. A firm's market value is the sum of the market value of its common stock, the book value of total debt, and preferred stock. The market value of equity is computed by multiplying the number of outstanding shares with the share price at year end. Cash flow is after tax profits before extraordinary items plus depreciation. ${ }^{23}$ All variables are deflated by the CPI $(1985=1.00)$. The average deal value was $\$ 307.2$ million with targets of tender offers ( $\$ 474.7$ million) being significantly larger than for mergers (\$283.9 million). This difference might be explained by the fact that tender offers were often intended to take over large diversified companies and spin off some of their assets. Firms making tender offers were nearly twice as large on average than acquirers in friendly mergers, so that the average target was only 10 percent of the acquirer's size in a tender offer, 26 percent in a merger. Mean Tobin's $q$ for acquirers in tender offers is not significantly different from that of the full sample. Acquirers in mergers had significantly higher $q$ s than other companies, however. Both types of acquirers have significantly higher levels of cash flows than non-acquirers. Overvaluation as a fraction of total assets amounts to 69.7 percent for acquirers in all acquisitions. Acquirers in friendly mergers are slightly more overvalued (71.6\%) than acquirers in tender offers (55.3\%). On the other hand, overvaluation of targets in all acquisitions is lower than these figures (43.7\%). More importantly, non-merging firms have the lowest overvaluation as a fraction of their total assets $(37.6 \%)$.

Table $2 \mathrm{~b}$ presents correlation coefficients of our main variables. Assets acquired in friendly mergers, $F M_{i t}$, are significantly correlated with $q, O_{i t}$ and the $\mathrm{P} / \mathrm{E}$ ratio. Assets 
acquired in tender offers, $\mathrm{TO}_{i t}$, have an insignificant correlation with Tobin's $q$, and are negatively correlated with the $\mathrm{P} / \mathrm{E}$ ratio and $O_{i t}$ (insignificant). Tobin's $q$ is highly correlated with our measure of overvaluation.

\section{Tests of the Industry Shocks Hypothesis}

We test the ISH by regressing the assets acquired in year $t$ by firm $i, M_{i t}$, on industry/time dummies, where the time dummies are defined for two-year intervals. Although most of the estimates to explain assets acquired presented in this article are made using the Tobit procedure, it did not converge for the large number of dummy variables used in this test, so we report only the OLS results in Table 3.

Equation 1 is the benchmark equation and reveals that simply knowing what year it is explains two percent of the variation in assets acquired over the 1985-2002 period. The 12 time dummies are then replaced with 576 industry/time dummies - the same 12 time dummies each multiplied by the 48 industry dummies used by Harford (2004). The addition of 564 variables raises the $\mathrm{R}^{2}$ of the equation from 0.020 to 0.032 , a statistically significant increase, but the 576 industry/time dummies obviously leave much of merger activity unaccounted for. Regardless of the cause of a wave in a particular industry - a technological change, deregulation, import competition - if industry waves explain aggregate waves, then our procedure for measuring the importance of industry waves should capture their entire effect. We do not need to know why industry $j$ is undergoing a wave in year $t$, only that it is, and that firm $i$ is located in this industry to predict $i$ 's merger activity. Knowledge of a firm's industry location at a point in time does not explain a large fraction of merger activity, however, over and above the knowledge of what year it is. 
Harford adds several firm- and macro-level variables to explain merger activity. Most of these, like firm cash flows, appear in the other hypotheses that we test and, thus, do not discriminate among them and are left for discussion later. One variable that is specific to the ISH is the spread between the commercial and industrial loan rate and the federal funds rate, $C \& I_{t}$. We have questioned the logic for including this variable in the ISH, but add it to the 576 dummies anyway. We lose some 26,000 observations, because C\&I is available only as of 1986. It picks up the predicted negative coefficient and is statistically significant.

Another macroeconomic variable, the aggregate S\&P P/E ratio, figures in the MDH, and is correlated with $C \& I_{t}$ (see Table $2 b$ ). Thus the possibility exists that $C \& I_{t}$ is not measuring the tightness of the credit market and thus the cost of financing acquisitions, but rather is capturing the effect of the $\mathrm{S} \& \mathrm{P} \mathrm{P} / \mathrm{E}$. When $P / E_{t}$ is included, it has a positive and significant coefficient as predicted by the $\mathrm{MDH}$ and $\mathrm{OVH}$, and the coefficient on $C \& I_{t}$ is no longer significant (see eq. 4). Thus, $C \& I_{t}$ does not effectively test the ISH against the MDH.

\section{Explaining Assets Acquired}

The remaining three hypotheses about the determinants of mergers all take a conventional form in that they claim that certain sets of continuous variables explain merger activity. This section tests how well each set explains mergers.

A. The $q$-theory

The $q$-theory uses a single variable to explain the assets acquired by firm $i$ in $t$ - the difference between i's $q$ in $t-1, q_{\mathrm{it}-1}$, and the mean $q$ of all targets in $t-1, q_{\mathrm{Tt}-1}$. The 48 industry dummies used to test the ISH are also included in the regressions for all acquisitions and friendly mergers. There are far fewer tender offers in the sample than friendly mergers, and the Tobit estimation procedure failed to converge for tender offers, when the industry 
dummies were included. Thus all results for tender offers are Tobit estimates without controlling for industry differences. Where included, the industry dummies were statistically significant as a group. In the interest of space their coefficients are not reported. No time dummies were included, of course, since the assumption underlying each hypothesis is that its particular set of variables accounts for the time-series variation in merger activity.

In eq. 1 of Table 4 , the key variable of the $q$-theory, $q_{\mathrm{it}-1}-q_{\mathrm{Tt}-1}$, has a positive and highly significant coefficient as predicted.

What drives mergers under the $q$-theory are the potential gains from expanding the acquiring firm, as measured by its $q$, and the relative cheapness of the targets as represented by their average $q$. Given these two factors, whether a firm chooses to make an acquisition through a friendly merger or a tender offer should depend entirely on the relative transaction costs of each form of acquisition. The $q$-theory should explain both friendly mergers and tender offers equally well. Eqs. 2 and 3 in Table 4 test the $q$-theory separately for each type of acquisition. The results for friendly mergers again support the $q$-theory, but for tender offers the coefficient on $q_{\mathrm{it}-1}-q_{\mathrm{Tt}-1}$ is of the wrong sign, although statistically insignificant. These results for tender offers cast doubt on the $q$-theory.

Further doubt is cast when $q_{\mathrm{it}-1}-q_{\mathrm{Tt}-1}$ is separated into its two components. The coefficient on $q_{\mathrm{Tt}-1}$ should be equal in absolute value, but opposite in sign from that on $q_{\mathrm{it}-1}-$ the more expensive assets of ongoing companies are, the fewer mergers one sees. This prediction is resoundingly falsified. The coefficient on $q_{\mathrm{Tt}-1}$ is positive and 20 times that of $q_{\text {it-1. }}$. Moreover, entering the variables separately greatly increases the model's explanatory power (see eq. 4). Not only does merger activity not fall as the price of buying other firms rises, it increases dramatically. This result is unsurprising given the figures reported in Table 1 , but nevertheless constitutes a significant empirical refutation of the $q$-theory of mergers. 
B. The Overvaluation Hypothesis

In eq. 5 the coefficient on overvaluation is positive and significant as predicted. Under the OVH, the targets' managers are willing partners in mergers, and thus the OVH should receive more support for friendly mergers than for tender offers - and it does. Although the coefficient of $O_{i t}$ is positive and significant for both friendly mergers and tender offers, it is more than twice as large for friendly mergers implying a much greater sensitivity of this form of acquisition to overvaluation than for tender offers (see eqs. 6 and 7). ${ }^{24}$

Logically under the $\mathrm{OVH}$ the source of overvaluation should not matter, only its magnitude. Thus, when $O_{i t}$ is separated into the average overvaluation in the market, $O_{t}$, and firm $i$ 's deviation from this average, $d O_{i t}$, both variables should have identical coefficients $\left(O_{i t}=O_{t}+d O_{i t}\right)$. This prediction is resoundingly falsified. The coefficient on $O_{t}$ is some seven times larger than the one on $d O_{i t}$. What appears to drive mergers is not that some firms have overvalued shares and their managers wish to unload them, but rather that the entire market is overvalued. This market overvaluation can be viewed as measuring the degree of optimism in the market, and thus of the market's willingness to accept the overvalued shares of the acquirer. Although this finding is not totally inconsistent with the $\mathrm{OVH}^{25}$ it puts a considerably different twist on the hypothesis from the one put forward by its original proponents, $\mathrm{S} \& \mathrm{~V}$, and makes it more difficult to discriminate the $\mathrm{OVH}$ from the $\mathrm{MDH}{ }^{26}$

\section{The Managerial Discretion Hypothesis}

The MDH is expected to do better at explaining friendly mergers than tender offers, and so only the separate results for these two forms of acquisitions are reported. For friendly mergers all coefficients have the predicted signs and are highly significant (eq. 9). Note in particular the positive and significant coefficient on the interaction term between lagged cash 
flows and $q$. The larger $q$ is, the more discretion managers have to pursue their goals, and the more willing they are to use their cash flows to undertake friendly mergers.

The degree of (over) optimism in the market, the S\&P P/E, is highly significant. So too are the three firm size terms. Their coefficients imply an S-shaped relationship between size and acquired assets with the partial derivative changing in magnitude, but remaining positive, over the range of asset values. Size can be interpreted as an additional measure of managerial discretion. ${ }^{27}$

Eq. 10 tests the MDH for tender offers. As predicted, the fit is poorer than for friendly mergers - the pseudo $\mathrm{R}^{2}$ is lower, the coefficient on $q_{\mathrm{it}-1}$ is insignificant, and the coefficient on the $q_{\text {it- } 1} /$ cash flow interaction is of the wrong sign. We interpret this negative coefficient in the following way. The final transaction in a tender offer is almost always an exchange of cash for the target's shares. A firm with a high $q$ can raise cash by issuing shares, and is more likely to do so, the higher its share price $(q)$. Firms with low $q$ s are thus more dependent on their internal cash flows to finance tender offers, which accounts for the negative coefficient on the $q$ /cash flow interaction term. The importance of cash as the means for financing tender offers also explains the large coefficient on cash flows in eq. 10 .

In eq. $11, O_{t}$ is substituted for $P / E_{t}$. Like $P / E_{t}, O_{t}$ has a highly significant positive coefficient. The nearly indistinguishable effects of these two measures of market overvaluation imply that our results are insensitive to the way we measure overvaluation, and underscore the importance of the market's optimism in explaining friendly merger activity.

\section{Predicting the Probability of Being Acquired}

Under the OVH targets' managers want to cash in their stakes and are willing partners to mergers that do not generate wealth and saddle their shareholders with overvalued shares. 
Thus, the likelihood of a firm becoming the target of a friendly merger should be positively related to the size of the managers' stakes, $V S_{i t-1}$, and the extent to which they are overvalued, $O_{i t-1}$. We also include an interaction term between the two variables under the assumption that the greatest incentive to cash in will exist for managers with large financial stakes in highly overvalued companies. The results appear in eq. 1 of Table 5. None of the variables has a statistically significant coefficient. Other specifications using these variables also did not yield significant coefficients. A plausible implication of the $\mathrm{OVH}$ as it applies to the targets of mergers is not borne out.

We have argued that the $\mathrm{MDH}$ is more applicable to friendly mergers than tender offers. Tender offers reached their peak during the so-called hostile merger wave of the 1980s (see Table 1). The motivation behind many hostile takeovers was to replace the target's managers, who were thought to be doing a bad job running their firms. This explanation for mergers is known as the market-for-corporate-control hypothesis (MCCH). ${ }^{28}$ Under the MCCH targets should be underperforming in some sense, while neither the MDH nor the $\mathrm{OVH}$ necessarily predict that targets are performing poorly. If a large fraction of tender offers are explained by the $\mathrm{MCCH}$ and the $\mathrm{MDH}$ and $\mathrm{OVH}$ are more applicable to friendly mergers, we should observe differences in the characteristics of targets for the two types of acquisitions.

We test this prediction by running a probit regression, where the dependent variable is defined as one for firm $i$ in $t$, if it is acquired, zero otherwise. As explanatory variables we use $q$, size, cash flows and leverage ${ }^{29}\left(L_{i t-1}\right)$. In the friendly mergers equation, $q$ and size have negative and significant coefficients (eq. 2 in table 5). Targets of tender offers also have lower than average qs, but they have higher than average cash flow (eq. 3). These companies are clearly under performing as the $\mathrm{MCCH}$ predicts. 
The size of the target should be an important factor in explaining wealth-creating mergers. If a company wishes to make a tender offer for a company that is larger than itself, it should be able to raise the funds from a bank, if the merger will create wealth. If the tender offer succeeds the wealth generated by the merger will suffice to repay the loan. If it does not succeed, the bank need not give out any money. Similarly, a company should be able to issue shares to raise cash for a wealth-creating tender offer of any size, since the wealthcreating nature of the acquisition, combined with the assumption of capital market efficiency, ensures that the value of the company following the merger justifies the price paid for the newly issued shares. Thus, the fact that size's coefficient is insignificant in the tender offer equation and significant for friendly mergers illustrates that the rationales behind friendly mergers and tender offers are quite different.

Under the MDH it is the characteristics and motivation of the managers of the acquiring companies that drives mergers. Accordingly we expect and find that the variables predicted under the MDH are better at explaining friendly mergers than tender offers (see again Table 4). Under the MCCH, mergers are explained by the characteristics of the targets of mergers. Accordingly the variables predicted under the $\mathrm{MCCH}$ are better at explaining which firms become targets of tender offers than of friendly mergers (Table 5).

\section{Post-Merger Returns of Acquiring Companies}

The two neoclassical theories make identical predictions regarding the returns for acquiring companies' shareholders in both friendly mergers and tender offers - positive abnormal returns when the mergers are announced, and normal returns for longer windows after the mergers. Since all mergers are assumed to be wealth creating, both predictions should be supported for acquisitions made during merger waves and at other times. 
The predictions of the two behavioral theories are quite different. Acquirers' returns should be nonnegative at the mergers' announcements and negative for longer windows following the mergers. The returns from friendly mergers should be worse than from tender offers, and worse for mergers made during waves.

To test these predictions returns to acquirers are computed for windows of one month, and one, two and three years. Separate estimates are made for mergers during the great merger wave (1995-2000), and outside of it (1980-94 and 2001-2002). Our measure for abnormal return for an acquiring company $(A)$ over a $t+n$ month window is

$$
A R_{t+n}^{A}=R_{t+n}^{A}-R_{t+n}^{N A}
$$

where $R_{t+n}^{A}$ is the return of $A$ over the $n$ month window ( $n=1$ for one month, $n=12,24$, and 36 for one, two and three year windows, respectively) and $R_{t+n}^{N A}$ is the mean return on a portfolio of non-acquiring (NA) companies, which are in the same size decile as the acquiring company. The returns are calculated using the changes in the total return index from Datastream, which is adjusted for dividend payments and share splits.

The first set of estimates in Table 6 is for the announcement month. The mean returns for acquirers in friendly mergers are insignificantly different from zero. This finding contradicts the two neoclassical theories, but is consistent with the behavioral theories. ${ }^{30}$ Also consistent with the behavioral theories, are the higher returns to acquirers in tender offers than for friendly mergers, although only the mean returns for tender offers during the wave are significantly greater than zero.

The picture changes dramatically one year after the acquisitions. Shares of acquirers in friendly mergers have significant, negative abnormal returns, and mergers during the wave produce worse performance than non-wave mergers. These results are again inconsistent with the neoclassical theories, but exactly what the behavioral theories predict. Also 
consistent with the behavioral theories is the post-merger performance after one year of acquirers making tender offers during non-wave years. These are much larger than for friendly mergers and insignificantly different from zero. Many of these tender offers occurred during the so-called "hostile merger wave" of the 1980s and were targeted against poorly performing companies. As discussed above, the motivation behind these tender offers is likely to have been quite different from that behind friendly mergers. Tender offers made during the merger wave look quite different, however. Their post-merger share performance after one year is the worst of the four categories. The share performance of tender offers made during the wave matches the predictions of the behavioral theories. Indeed, the positive 2.23 percent returns made by these firms in the announcement month coupled with the -10.88 percent returns recorded after one year implies a good deal of optimism by the market regarding tender offers during waves - optimism that within a year had vanished.

The post-merger returns after two and three years further substantiate the inferences from the one-year results. Abnormal returns for friendly mergers decline with each passing year, with friendly mergers during the wave faring significantly worse than those outside the wave. After three years the mean abnormal return for an acquirer in a friendly merger during the wave was -31 percent. In half of these mergers it exceeded -42 percent. Shareholders of firms making tender offers during the wave suffered the largest post-merger losses, however, while tender offers in non-wave years produced the smallest losses. These results offer no support for the neoclassical theories' claim that mergers create wealth, while strongly confirming the predictions of the two behavioral hypotheses. ${ }^{31}$

The results in Table 6 support the two behavioral hypotheses, but do not readily allow one to discriminate between them. We thus close this section by testing a key prediction of the $\mathrm{OVH}$, namely that the shareholders of acquirers with overvalued shares benefit from the mergers, because the shares are traded for real assets. We do this by regressing acquirers' 3- 
year post-merger returns on the overvaluation variables used in the test of the $\mathrm{OVH}^{32}$ If the mergers benefited the acquirers' shareholders, they should earn higher returns over the postmerger period than shareholders of overvalued firms that did not undertake an acquisition. Since we identify the time of a merger by the month in which it is announced, our 3-year returns for mergers in, say March of 1995, are for the next 36 months. The sample of nonmerging firms for that month consists of all companies that did not make an acquisition in the 12 months prior to March 1995, and in the following 36 months. We estimate separate regressions for the whole sample period (1981-2001) and both the wave and non-wave periods and include the log of assets as a control variable. Since the two behavioral hypotheses are more plausible for friendly mergers, we report only the results for these.

Under the efficient capital market assumption, none of the three variables in an equation to explain 3-year returns should have a significant coefficient and the equation's $\mathrm{R}^{2}$ should be zero. The $\mathrm{R}^{2} \mathrm{~s}$ in Table 7 are indeed low, but nine of the twelve coefficients on the overvaluation variables are significant at the one percent level as is one coefficient on size. Eqs. 1 and 2 imply that a company of average size that was not overvalued and did not make an acquisition had predicted 3-year return of 76 percent during the non-wave years, and 80 percent during the wave (see second last column, calculated by adding the intercept to the coefficient on size multiplied by its mean). The same calculations for acquiring firms yield predicted returns of -17 and 37 percent. Thus, if there had been no overvaluation of any kind, the 3-year returns of acquirers would have been much worse than that of non-acquirers.

All twelve coefficients on the overvaluation variables are negative as one expects, if the capital market is not efficient and the variables actually do measure overvaluation. Moreover, the coefficients on the market's overvaluation, $O_{t-1}$, are much larger for both acquirers and non-acquirers during the wave years, as one expects if market overvaluation is driving the wave. The last column in Table 7 presents the predicted returns for a firm, when 
all three variables are evaluated at their means. Since the market overvaluation variable has the largest negative coefficients and the means of this variable are all positive, the 3 -year returns calculated at the variables' means are much lower than for a firm with no overvaluation. After three years the market appears to have corrected some or all of its overvaluation for both acquiring and non-acquiring companies.

The OVH claims to explain merger waves, and that overvalued acquirers do better as a result of the mergers than they would have done in their absence. This prediction is not confirmed by the results in Table 7. During the wave period, the predicted 3-year returns for acquirers had there been no overvaluation are 43 percentage points below those for nonacquirers (second last column). When evaluated at the overvaluation means, the difference increases to 52 percent (last column). The mergers appear to have done nothing to soften the negative effect on returns of being overvalued. Thus, the results in Table 7 confirm those from Table 6 that mergers are bad for the acquirers' shareholders, and reject the OVH's prediction that mergers mediate the negative effects of overvaluation for acquirers' shareholders.

\section{Discussion}

As an explanation of merger waves the $q$-theory runs as follows. At certain points in time the capital market perceives that many firms are very well-managed and bids up their share prices producing high $q$ s and a stock market boom. High- $q$ firms can profitably expand by acquiring other firms, because this is cheaper than acquiring used capital equipment.

Of the four theories, the $q$-theory receives the least support. Logically it suffers from the fact that new plant and equipment can always be purchased at a $q$ of 1.0 , and the $q$ s of targets sore to values greatly in excess of 1.0 during merger waves. The theory is empirically 
refuted by the strong positive relationship between the qs of targets and the amounts of assets acquired. Once this implication of the theory is dropped, one is left with the prediction that firms with high $q$ s undertake mergers. Since this prediction is common to both the OVH and $\mathrm{MDH}$, it does not effectively discriminate the $q$-theory from them.

The ISH explains merger waves by a coincidence of two events: (1) numerous industries experience various shocks, which make mergers profitable, and (2) favorable macro-conditions reduce the costs of financing acquisitions. The ISH's key measure of borrowing costs turns out to be correlated with the aggregate S\&P P/E, and becomes insignificant when this variable is included in an equation to explain assets acquired under the ISH. This empirical finding raises the possibility that the shocks generating simultaneous industry waves and thus an aggregate wave are in fact a single "shock" - the rise in market optimism reflected by the rise in the $\mathrm{P} / \mathrm{E}$, as hypothesized under the $\mathrm{MDH}$.

Both neoclassical theories assume that managers maximize shareholders' wealth, mergers generate wealth, and thus that acquirers earn positive abnormal returns. Our results fail to confirm this prediction. Only tender offers during the merger wave produced a positive and significant return for acquirers in the announcement month - a modest 2.23 percent. These tender offers make up less than five percent of our sample. Both types of acquisitions had significant negative returns to acquirers over longer windows, with the acquirers' share performance worsening with the time the market had to evaluate them. This finding - modest or zero returns to acquirers at merger announcements, substantial negative returns over longer periods following announcements - is not new. Indeed, it constitutes one of the great riddles in the literature on mergers - at least for those who assume that managers maximize shareholder wealth and equity markets are efficient. ${ }^{33}$

Both behavioral theories predict these post-merger losses to acquirers, although for different reasons. Under the $\mathrm{OVH}$, the market's overvaluation, which precipitated the 
merger, is eventually corrected and the acquirer's share price falls back to its warranted level. Under the MDH, the acquirer's share price eventually falls, because it paid a premium for the target, when there were no synergistic gains to justify it, and perhaps incurred transaction costs and perhaps other inefficiencies in integrating the two companies.

A puzzle under the $\mathrm{OVH}$ is why during the stock market boom that accompanies a merger wave, managers choose to exchange their overvalued shares for the overvalued shares of other firms, and pay a premium to do so, rather than retiring their debt, or buying other assets that are not overvalued. One explanation for this behavior might be that an announcement of a swap of equity for debt or the purchase of real estate would signal that a firm's shares are overvalued and lead to an immediate market correction. If this explanation accounts for mergers during stock market booms, then the OVH rests not only on the assumption that acquirers' shares are overvalued, but also that this overvaluation can be prolonged only by exchanging these shares for those of other firms. This interpretation is supported by our finding that the explanatory power of a company's own overvaluation is dwarfed by the level of market overvaluation - a measure of overall optimism in the market and the willingness of shareholders of targets to accept overvalued shares in exchange for their shares. Since this variable is prominent in the $\mathrm{MDH}$, its empirical weight makes it difficult to discriminate between the two behavioral theories. One test that did discriminate between them went against the OVH. Companies that have overvalued shares do not benefit their shareholders by undertaking mergers. They earn lower returns than similarly overvalued firms that do not merge.

Thus, based on our empirical results we offer the following account of merger waves. At some points in time, shareholder optimism begins to rise. This optimism is fed by various "theories" as to why share prices should rise. Among these are theories as to why mergers in certain industries, or by certain firms (e.g., the conglomerates) will generate wealth. This 
optimism in the market allows managers to undertake wealth-destroying acquisitions, and not have their announcements met by immediate declines in their companies' share prices. The number of wealth-destroying mergers increases dramatically during a stock market boom creating a merger wave. As the market learns about the mergers, it realizes that they will not produce synergies, and that the theories behind them were false. The market's optimism disappears and the share prices of acquiring firms fall relative to those of other companies. Because of the premia paid for the targets and the transaction costs of integrating separate companies, the losses to shareholders of companies making acquisitions are greater than one expects, simply because the acquiring companies were overvalued. 


\section{References:}

Amihud Y. and B. Lev, 1981, Risk reduction as a managerial motive for conglomerate mergers, The Bell Journal of Economics, 1981, 605- 617.

Andrade, Gregor, and Erik Stafford, 2004, Investigating the Economic Role of Mergers, Journal of Corporate Finance, 10, 1-36.

Ang, J. and Y. Cheng, 2003, Direct Evidence on Stock Market Driven Acquisitions Theory, Florida University Working Paper.

Caves, R. E., 1989, R. E., 1989, Mergers, Takeovers, and Economic Efficiency, International Journal of Industrial Organization, 7, 151-174.

Chappell, H. W. and D. C. Cheng 1984, Firms, Acquisition Decisions and Tobin's q Ratio, Journal of Economics and Business, 36, January, 29-42.

Comanor, William S., 1967, Vertical Mergers, Market Power, and the Antitrust Laws, American Economic Review, 57, 254-65.

Dong, Ming, David Hirschleifer, Scott Richardson, Siew Hong Teoh, 2003, Does Investor Misvaluation Drive the Takeover Market? Working Paper.

Economist, 1991, A Survey of International Finance (From Morgan's Nose to Milken's Wig), April 27th, 8-12.

Erard, B. and H. Schaller, 2002, Acquisitions and Investment, Economica, 69, 391-414.

Fama, Eugene F. and Kenneth R. French, Industry Costs of Equity, Journal of Financial Economics, 43, 153-193.

Fisher, A. B. 1984, The Decade's Worst Mergers, Fortune, April 30, 1984, pp. 262- 270.

Galbraith, John Kenneth, 1961, The Great Crash: 1929, $2^{\text {nd }}$ ed. Boston: Houghton Mifflin.

Golbe, Devra L., and Lawrence J White, 1993, Catch a Wave: The Time Series Behavior of Mergers, The Review of Economics and Statistics, 75, 493-499.

Grabowski, H., and Mueller, Dennis C., 1972, Managerial and Stockholder Welfare Models of Firm Expenditures, Review of Economics and Statistics 54, 9-24.

Gugler, Klaus, Dennis C. Mueller and B. Burcin Yurtoglu, 2004, Marginal q, Tobin's q, Cash Flow and Investment, Southern Economic Journal, 70 (3), 512-531. 
Harford, Jarrod, 2004, What Drives Merger Waves? Journal of Financial Economics (forthcoming).

Hay, Donald A. and Guy S Liu, 1998, When do Firms go in for Growth by Acquisitions? Oxford Bulletin of Economics and Statistics, 60(2), 143-64.

Heckman, J. 1976, The Common Structure of Statistical Models of Truncation, Sample Selection, and Limited Dependent Variables and a Simple Estimator for such Models, The Annals of Economic and Social Measurement 5: 475-492.

Jensen, Michael C. and R.S. Ruback, 1983, The Market for Corporate Control: The Scientific Evidence, Journal of Financial Economics, 11, 5-50.

Jovanovic and Rousseau, 2002, The Q-Theory of Mergers, American Economic Review Papers and Proceedings, May, 198-204.

Khorana, Ajay and Marc Zenner, 1998, Executive compensation of large acquirors in the 1980s, Journal of Corporate Finance, 4, pp. 209-240.

Linn, Scott C. and Zhen Zhu, 1997, Aggregate Merger Activity: New Evidence on the Wave Hypothesis, Southern Economic Journal, 64, July, 130-46.

Lown, C., Morgan, D., and Rohatgi, S., 2000, Listening to Loan Officers: The Impact of Commercial Credit Standards on Lending and Output, FRBNY Economic Policy Review, July, 1-16.

Manne, Henry G. (1965): Mergers and the Market for Corporate Control, Journal of Political Economy, 73, 110-120.

Marris, Robin, 1964, The Economic Theory of Managerial Capitalism, Glencoe: Free Press.

Marris, Robin, 1998, Managerial Capitalism in Retrospect, Palgrave-Macmillan, London.

Mitchell, Mark L., and J. Harold Mulherin, 1996, The Impact of Industry Shocks on Takeover and Restructuring Activity, Journal of Financial Economics, 41(2), 193 229.

Moeller, Sara B., Frederik P. Schlingemann and Rene M. Stulz, 2005, Wealth Destruction on a Massive Scale? A Study of Acquiring-firm Returns in the Recent Merger Wave, forthcoming in Journal of Finance, April.

Mueller, 1977, The Effects of Conglomerate Mergers: A Survey of the Empirical Evidence, Journal of Banking and Finance, 1, 315-47. 
Mueller, Dennis C. 1969, A Theory of Conglomerate Mergers, Quarterly Journal of Economics, 83, November, 643-59.

Mueller, Dennis C. and Mark L. Sirower, 2003, The Causes of Mergers: Tests Based on the Gains to Acquiring Firms' Shareholders and the Size of Premia, Managerial and Decision Economics, 24 (5), 373-416.

Mueller, Dennis C., 2003, The Corporation: Investment, Mergers, and Growth, Routledge, London.

Mulherin, J.H. and A. Boone, 2000, Comparing Acquisitions and Divestitures, Journal of Corporate Finance 6, 117-139.

Nelson, Ralph L. 1966, Business Cycle Factors in the Choice Between Internal and External Growth, in W. Alberts and J. Segall, eds., The Corporate Merger, Chicago: University of Chicago Press.

Nelson, Ralph, L. 1959, Merger Movements in American Industry, 1895-1956, Princeton: Princeton University Press.

Perfect, S.B. and K.W. Wiles, 1994, Alternative Constructions of Tobin's q: An Empirical Comparison, Journal of Empirical Finance (July), 313-341.

Resende, Marcelo, 1999, Wave Behaviour of Mergers and Acquisitions in the UK: A Sectoral Study, Oxford Bulletin of Economics and Statistics, 61(1), 85-94.

Rhodes-Kropf, M. and S. Viswanathan, 2003, Market Valuation and Merger Waves, Working Paper.

Rhodes-Kropf, M., David. T. Robinson, and S. Viswanathan, 2003, Valuation Waves and Merger Activity: The Empirical Evidence, Working Paper.

Roe, Mark J. 1993. Takeover politics, in: Margaret M. Blair (Ed.) The Deal Decade, The Brookings Institution, Washington, D.C.

Scherer, F.M. and David Ross, 1990, Industrial Market Structure and Economic Performance, 3rd ed., Boston: Houghton Mifflin.

Schwartz, S., 1984, An Empirical Test of A Managerial, Life-Cycle, and Cost of Capital Model of Merger Activity, Journal of Industrial Economics, 32(3), 265-75.

Schwert, G.W., 2000, Hostility in Takeovers: In the Eyes of the Beholder? Journal of Finance, 55 (6), 2599-2640. 
Schwert, G.W., 1996, Markup Pricing in Mergers \& Acquisitions, Journal of Financial Economics, 41, 153-192.

Shiller, Robert J., 2000, Irrational Exuberance, Princeton: Princeton University Press.

Shleifer, Andrei and Robert W. Vishny, 2003, Stock Market Driven Acquisitions, Journal of Financial Economics, 70 (3), 295-489.

Verter, 2002, Timing Merger Waves, Harvard University, Mimeo.

Vogt, S. C., 1994, The Cash Flow/Investment Relationship: Evidence from U.S. Manufacturing Firms, Financial Management, 23, 3-20.

Weston, Fred J., Kwang S. Chung, and Susan E. Hoag, 1990, Mergers, Restructuring, and Corporate Control, New Jersey: Prentice Hall.

Williamson, Oliver E., 1975, Markets and Hierarchies: Analysis and Antitrust Implications, New York: Free Press. 
Figure 1:

\section{Mergers and Average P/E ratio}

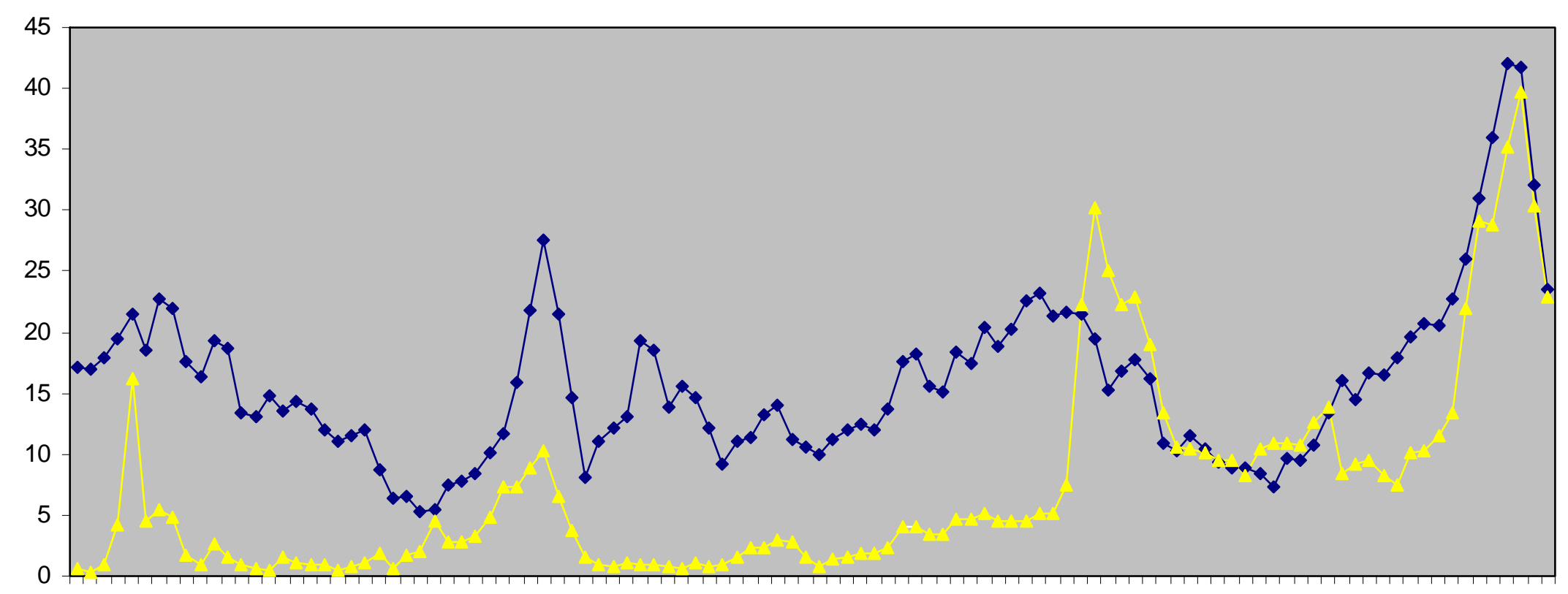

1895190019051910191519201925193019351940194519501955196019651970197519801985199019952000 Year

$\multimap$ Average P/E $\multimap$ Mergers/Population

Sources: Mergers: 1895-1920 from Nelson (1959); 1921-67 from FTC; 1968-2002 from M\&A.

P/E ratios: Homepage of Robert Shiller: http://aida.econ.yale.edu/ shiller/data.htm. Population: Statistical Abstract of United States (several years). 
Figure 2: The Managerial Trade-off

Figure (2a)

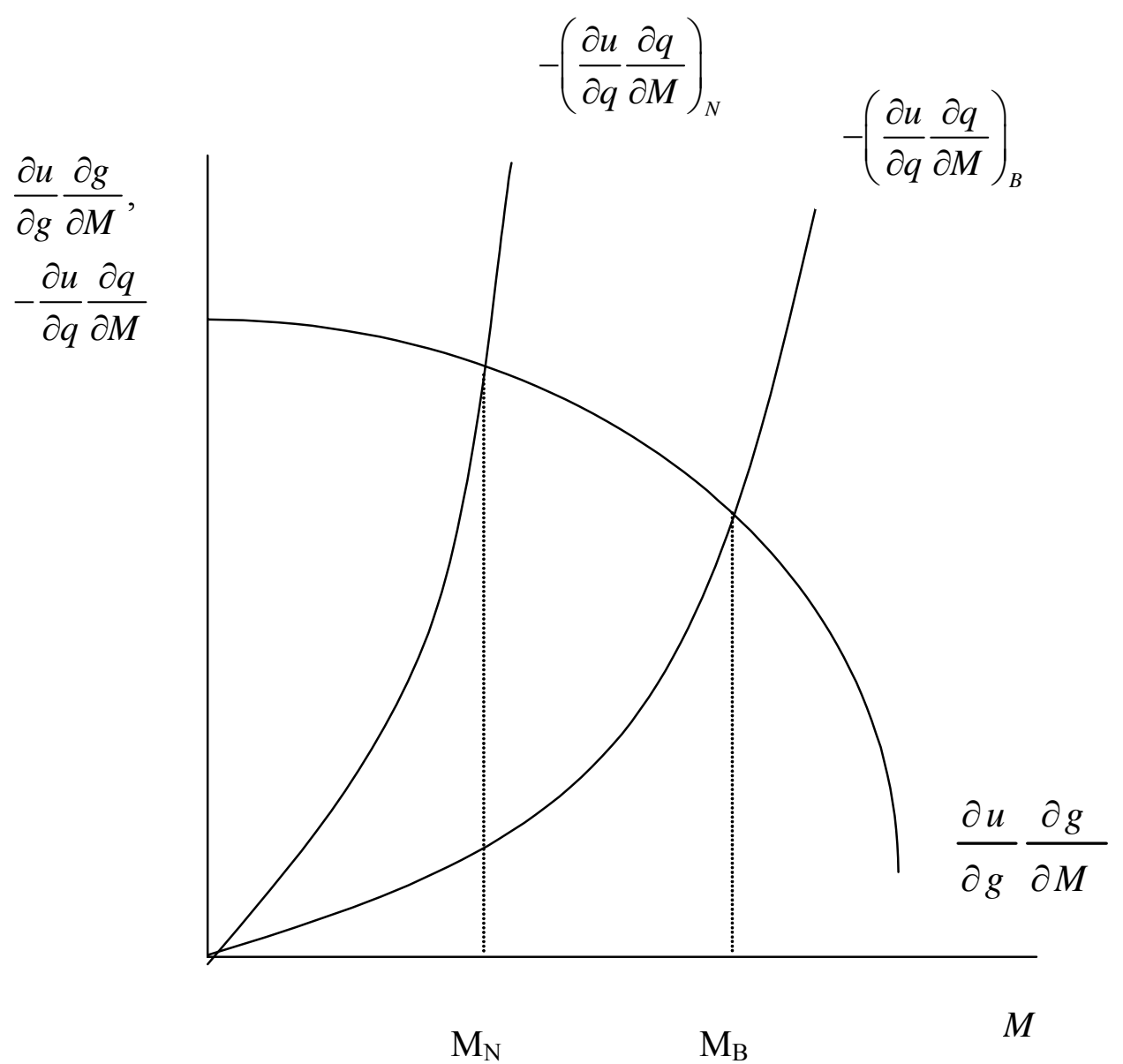

Figure (2b)

$q$

.0

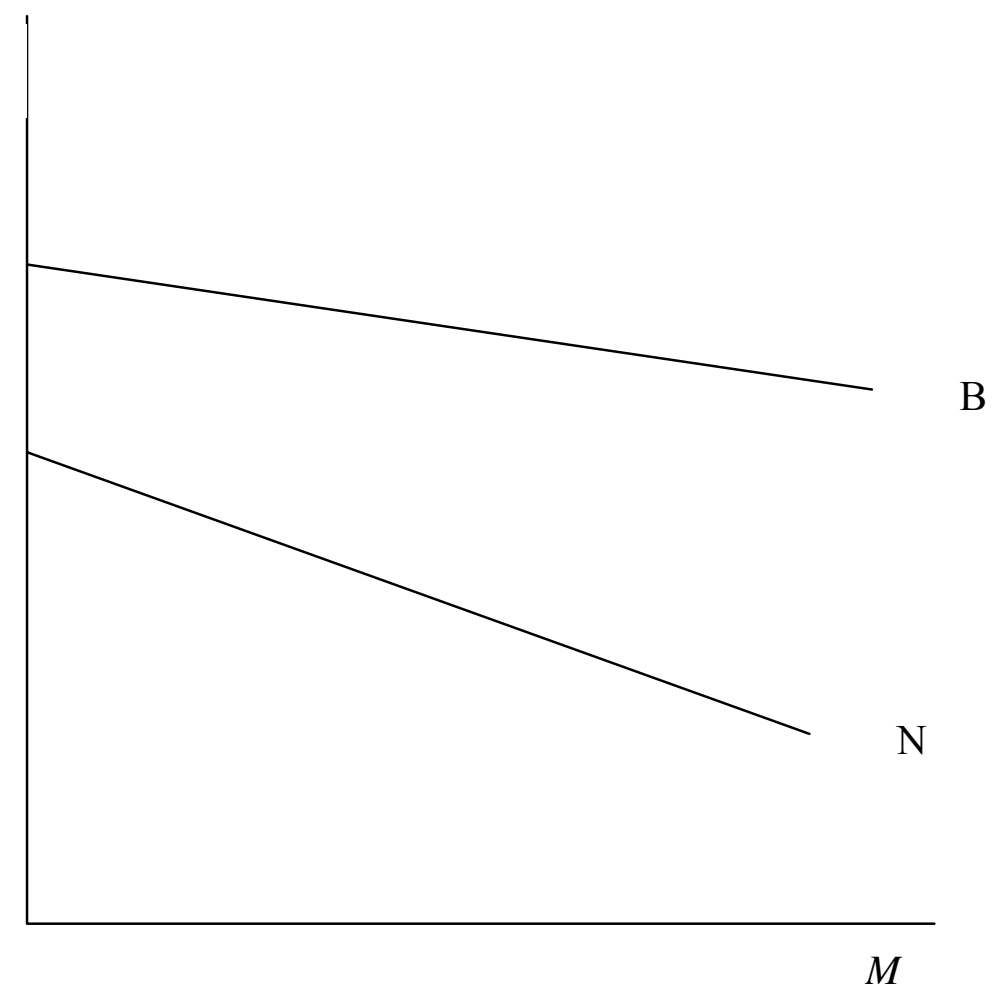


Table 1: Number of Acquirers and Targets in Friendly Mergers (FM) and Tender Offers (TO) and Mean Tobin's qs

\begin{tabular}{|c|c|c|c|c|c|c|c|c|c|}
\hline \multirow{3}{*}{ Year } & \multirow{3}{*}{ FM } & \multirow{3}{*}{ TO } & \multirow{3}{*}{$\%$ TO } & \multicolumn{2}{|c|}{ Acquirers } & \multicolumn{4}{|c|}{ Targets } \\
\hline & & & & FM & TO & FM & FM & TO & TO \\
\hline & & & & $\begin{array}{l}\text { Market Value / } \\
\text { Total Assets }\end{array}$ & $\begin{array}{c}\text { Market Value / } \\
\text { Total Assets }\end{array}$ & $\begin{array}{c}\text { Market Value / } \\
\text { Total Assets }\end{array}$ & $\begin{array}{l}\text { Deal Value / } \\
\text { Total Assets }\end{array}$ & $\begin{array}{c}\text { Market Value / } \\
\text { Total Assets }\end{array}$ & $\begin{array}{l}\text { Deal Value / } \\
\text { Total Assets }\end{array}$ \\
\hline 81 & 205 & 14 & $6.39 \%$ & 1.275 & 0.664 & 1.011 & 0.756 & 1.066 & 0.787 \\
\hline 82 & 311 & 23 & $6.89 \%$ & 1.216 & 0.906 & 0.846 & 0.829 & 0.758 & 0.711 \\
\hline 83 & 486 & 23 & $4.52 \%$ & 1.377 & 0.781 & 1.052 & 1.018 & 0.797 & 0.804 \\
\hline 84 & 478 & 29 & $5.72 \%$ & 1.411 & 0.921 & 1.218 & 1.097 & 1.073 & 0.897 \\
\hline 85 & 166 & 41 & $19.81 \%$ & 1.154 & 0.902 & 1.085 & 1.465 & 1.075 & 1.754 \\
\hline 86 & 156 & 56 & $26.42 \%$ & 1.245 & 1.001 & 1.234 & 1.654 & 1.232 & 1.815 \\
\hline 87 & 177 & 47 & $20.98 \%$ & 1.380 & 1.118 & 1.204 & 1.564 & 1.140 & 1.662 \\
\hline 88 & 181 & 60 & $24.90 \%$ & 1.298 & 1.316 & 1.384 & 2.048 & 1.046 & 1.757 \\
\hline 89 & 273 & 55 & $16.77 \%$ & 1.327 & 0.998 & 1.306 & 1.588 & 1.266 & 2.008 \\
\hline 90 & 318 & 26 & $7.56 \%$ & 1.532 & 1.356 & 1.341 & 1.435 & 1.253 & 1.694 \\
\hline 91 & 346 & 19 & $5.21 \%$ & 1.459 & 1.282 & 1.397 & 1.857 & 1.274 & 2.144 \\
\hline 92 & 513 & 16 & $3.02 \%$ & 1.873 & 2.034 & 1.343 & 2.123 & 1.133 & 1.720 \\
\hline 93 & 607 & 25 & $3.96 \%$ & 1.681 & 1.557 & 1.384 & 2.096 & 1.706 & 2.548 \\
\hline 94 & 726 & 33 & $4.35 \%$ & 1.644 & 1.732 & 1.238 & 2.060 & 1.259 & 2.556 \\
\hline 95 & 817 & 57 & $6.52 \%$ & 1.623 & 1.570 & 1.147 & 2.292 & 1.503 & 2.951 \\
\hline 96 & 960 & 55 & $5.42 \%$ & 1.803 & 1.581 & 1.490 & 2.819 & 1.200 & 2.525 \\
\hline 97 & 1001 & 73 & $6.80 \%$ & 1.902 & 1.652 & 1.213 & 2.295 & 1.057 & 2.340 \\
\hline 98 & 599 & 72 & $10.73 \%$ & 2.004 & 1.732 & 1.590 & 3.095 & 1.274 & 2.602 \\
\hline 99 & 588 & 63 & $9.68 \%$ & 2.218 & 1.860 & 1.687 & 3.109 & 1.498 & 2.216 \\
\hline 100 & 550 & 63 & $10.28 \%$ & 2.708 & 1.646 & 2.012 & 2.340 & 1.886 & 2.076 \\
\hline 101 & 453 & 47 & $9.40 \%$ & 1.962 & 2.416 & 1.490 & 2.281 & 1.091 & 1.865 \\
\hline 102 & 339 & 37 & $9.84 \%$ & 1.705 & 2.006 & 0.862 & 1.000 & 1.017 & 1.468 \\
\hline Total & 10250 & 934 & $8.35 \%$ & 1.742 & 1.489 & 1.298 & 1.976 & 1.118 & 1.854 \\
\hline Wave & 4515 & 383 & $7.82 \%$ & 1.988 & 1.683 & 1.433 & 2.611 & 1.358 & 2.471 \\
\hline Non-wave & 5735 & 551 & $8.77 \%$ & 1.548 & 1.347 & 1.216 & 1.589 & 1.117 & 1.618 \\
\hline
\end{tabular}

Note: The market value of the firm is equal to the sum of market value of equity and the book value of debt. Deal value is the total amount paid for target in year $t$. 


\begin{tabular}{|c|c|c|c|}
\hline & $\begin{array}{c}\text { All } \\
\text { Acquisitions }\end{array}$ & $\begin{array}{l}\text { Tender } \\
\text { Offers }\end{array}$ & $\begin{array}{l}\text { Friendly } \\
\text { Mergers }\end{array}$ \\
\hline \multicolumn{4}{|l|}{ Acquirer characteristics: } \\
\hline Tobin's $q$ & 1.71 & 1.48 & 1.74 \\
\hline Overvaluation ( $\%$ of Total assets) & 69.7 & 55.3 & 71.6 \\
\hline Cash flow/Total assets & 0.064 & 0.094 & 0.060 \\
\hline Total assets (Mn 1985 USD) & 4828.1 & 8296.6 & 4461.0 \\
\hline \multicolumn{4}{|l|}{ Target characteristics: } \\
\hline Tobin's $q$ & 1.28 & 1.18 & 1.33 \\
\hline Overvaluation ( $\%$ of Total assets) & 43.7 & 34.6 & 48.6 \\
\hline Cash flow/Total assets & 0.037 & 0.079 & 0.021 \\
\hline Deal Value (Mn 1985 USD)* & 307.32 & 474.76 & 283.91 \\
\hline \multirow[t]{2}{*}{$M_{i t}$} & 0.121 & 0.168 & 0.116 \\
\hline & \multicolumn{3}{|c|}{ Non-merging firms: } \\
\hline Tobin's $q$ & \multicolumn{3}{|c|}{1.50} \\
\hline Overvaluation ( $\%$ of Total assets) & \multicolumn{3}{|c|}{37.6} \\
\hline Cash flow/Total assets & \multicolumn{3}{|c|}{0.014} \\
\hline Total assets (Mn 1985 USD) & \multicolumn{3}{|c|}{503.6} \\
\hline
\end{tabular}

Note: Tobin's q is the market value of the firm divided by book value of assets; Overvaluation is $O_{i t}$ from equation (4); $M_{i t}$ is the total amount paid for the target divided by total assets. For this variable, we report only firm years with deals.

Table 2b: Correlation Coefficients

\begin{tabular}{|c|c|c|c|c|c|c|c|c|c|c|c|c|c|c|}
\hline & \multicolumn{2}{|c|}{$M_{i t}$} & \multicolumn{2}{|c|}{$q_{i t}$} & \multicolumn{2}{|c|}{$C F_{i t-1}$} & \multicolumn{2}{|c|}{$O_{i t}$} & \multicolumn{2}{|c|}{$K_{i t-1}$} & \multicolumn{2}{|c|}{$P / E_{t}$} & \multicolumn{2}{|c|}{$C \& I_{t}$} \\
\hline & FM & TO & FM & TO & FM & TO & FM & TO & FM & TO & FM & TO & FM & TO \\
\hline$M_{i t}$ & 1.00 & 1.000 & & & & & & & & & & & & \\
\hline \multirow[t]{2}{*}{$q_{i t}$} & 0.247 & 0.054 & 1.000 & 1.000 & & & & & & & & & & \\
\hline & 0.000 & 0.138 & & & & & & & & & & & & \\
\hline \multirow[t]{2}{*}{$C F_{i t-1}$} & -0.081 & -0.101 & -0.029 & 0.124 & 1.000 & 1.000 & & & & & & & & \\
\hline & 0.000 & 0.005 & 0.013 & 0.001 & & & & & & & & & & \\
\hline \multirow[t]{2}{*}{$O_{i t}$} & 0.244 & -0.037 & 0.661 & 0.597 & 0.138 & 0.168 & 1.000 & 1.000 & & & & & & \\
\hline & 0.000 & 0.345 & 0.000 & 0.000 & 0.000 & 0.000 & & & & & & & & \\
\hline \multirow[t]{2}{*}{$K_{i t-1}$} & -0.081 & -0.142 & -0.104 & -0.071 & -0.015 & -0.081 & -0.074 & -0.027 & 1.000 & 1.000 & & & & \\
\hline & 0.000 & 0.000 & 0.000 & 0.051 & 0.197 & 0.025 & 0.000 & 0.484 & & & & & & \\
\hline \multirow[t]{2}{*}{$P / E_{t}$} & 0.124 & -0.108 & 0.189 & 0.258 & -0.064 & 0.054 & 0.187 & 0.284 & 0.090 & 0.104 & 1.000 & 1.000 & & \\
\hline & 0.000 & 0.003 & 0.000 & 0.000 & 0.000 & 0.139 & 0.000 & 0.000 & 0.000 & 0.004 & & & & \\
\hline \multirow{2}{*}{$C \& I_{t}$} & -0.048 & -0.121 & 0.031 & 0.106 & -0.007 & -0.008 & -0.006 & 0.065 & 0.047 & 0.059 & 0.100 & 0.240 & 1.000 & 1.000 \\
\hline & 0.000 & 0.002 & 0.016 & 0.007 & 0.606 & 0.846 & 0.675 & 0.113 & 0.000 & 0.133 & 0.000 & 0.000 & & \\
\hline
\end{tabular}


Table 3: Tests of the Industry Shocks Hypothesis

\begin{tabular}{|c|c|c|c|c|c|}
\hline Equation & Dummy variables & $C \& I_{t}$ & $P / E_{t}$ & $n$ & $\bar{R}^{2}$ \\
\hline 1 & 12 2-year time dummies & & & 89946 & 0.020 \\
\hline 2 & 576 2-year time / industry dummies & & & 89946 & 0.032 \\
\hline 3 & 576 2-year time / industry dummies & $\begin{array}{l}-0.011 \\
(3.39)\end{array}$ & & 63206 & 0.028 \\
\hline 4 & 576 2-year time / industry dummies & $\begin{array}{c}-0.0049 \\
(1.38)\end{array}$ & $\begin{array}{c}0.0009 \\
(5.68)\end{array}$ & 63206 & 0.035 \\
\hline
\end{tabular}

Notes: t-statistics are below coefficients. 


\section{Table 4 Explaining the Amounts of Assets Acquired}

\begin{tabular}{|c|c|c|c|c|c|c|c|c|c|c|c|}
\hline Eq. & 1 & 2 & 3 & 4 & 5 & 6 & 7 & 8 & 9 & 10 & 11 \\
\hline Hyp & $\mathrm{QH}$ & QH & $\mathrm{QH}$ & $\mathrm{QH}$ & OVH & OVH & OVH & OVH & MDH & MDH & MDH \\
\hline Type & ALL & FM & TO & ALL & ALL & $\mathrm{FM}$ & TO & $\mathrm{FM}$ & FM & TO & $\mathrm{FM}$ \\
\hline $\begin{array}{l}\text { Industry } \\
\text { dummies }\end{array}$ & Yes & Yes & No & Yes & Yes & Yes & No & Yes & Yes & No & Yes \\
\hline \multirow[t]{2}{*}{$q_{i t-1}-q_{T t-1}$} & 0.023 & 0.025 & -0.004 & & & & & & & & \\
\hline & 15.17 & 16.37 & 0.84 & & & & & & & & \\
\hline \multirow[t]{2}{*}{$q_{i t-1}$} & & & & 0.022 & & & & & 0.027 & 0.0058 & 0.032 \\
\hline & & & & 14.62 & & & & & 16.69 & 1.13 & 19.37 \\
\hline \multirow[t]{2}{*}{$q_{T t-1}$} & & & & 0.440 & & & & & & & \\
\hline & & & & 25.06 & & & & & & & \\
\hline \multirow[t]{2}{*}{$O_{i t}$} & & & & & 0.072 & 0.078 & 0.031 & & & & \\
\hline & & & & & 22.8 & 23.56 & 3.66 & & & & \\
\hline \multirow[t]{2}{*}{$d O_{i t}$} & & & & & & & & 0.062 & & & \\
\hline & & & & & & & & 18.82 & & & \\
\hline \multirow[t]{2}{*}{$O_{t}$} & & & & & & & & 0.42 & & & 0.48 \\
\hline & & & & & & & & 29.79 & & & 36.07 \\
\hline \multirow[t]{2}{*}{$P / E_{t}$} & & & & & & & & & 0.012 & 0.012 & \\
\hline & & & & & & & & & 40.53 & 14.62 & \\
\hline \multirow[t]{2}{*}{$C F_{i t-1}$} & & & & & & & & & 0.21 & 1.05 & 0.19 \\
\hline & & & & & & & & & 7.89 & 9.21 & 7.15 \\
\hline \multirow[t]{2}{*}{$q_{i t} C F_{, i t-1}$} & & & & & & & & & 0.022 & -0.078 & 0.027 \\
\hline & & & & & & & & & 3.70 & 3.81 & 4.64 \\
\hline \multirow[t]{2}{*}{$K_{t-1}$} & & & & & & & & & $9.3^{*^{10-6}}$ & $2.0^{* 10-5}$ & $1.0^{* 10-5}$ \\
\hline & & & & & & & & & 17.83 & 14.60 & 19.07 \\
\hline \multirow[t]{2}{*}{$K_{t-1}^{2}$} & & & & & & & & & $-5.5^{\star^{10-11}}$ & $-1.2^{\star^{10-10}}$ & $-5-9^{*^{10-11}}$ \\
\hline & & & & & & & & & 13.39 & 10.62 & 14.14 \\
\hline \multirow[t]{2}{*}{$K_{t-1}^{3}$} & & & & & & & & & $7.1^{\star^{10-17}}$ & $1.6^{\star^{10-16}}$ & $7.5^{\star^{10-17}}$ \\
\hline & & & & & & & & & 11.22 & 9.52 & 11.87 \\
\hline $\mathrm{N}$ & 86697 & 85887 & 79432 & 86647 & 50897 & 50238 & 45974 & 50238 & 89182 & 82724 & 89182 \\
\hline $\mathrm{R}^{2}$ & 0.036 & 0.043 & 0.0001 & 0.058 & 0.06 & 0.073 & 0.002 & 0.11 & 0.137 & 0.102 & 0.122 \\
\hline $\begin{array}{l}\text { Consistent } \\
\text { with } \\
\text { Hypothesis }\end{array}$ & Yes & Yes & No & No & Yes & Yes & Yes & No & Yes & Yes & Yes \\
\hline
\end{tabular}

Notes: Dependent variable is $M_{i t}$. See the text for the definition of the independent variables. t-statistics are below coefficients. 
Table 5: Explaining the Identities of Targets (Probit Estimates)

\begin{tabular}{|c|c|c|c|}
\hline Eq. & 1 & 2 & 3 \\
\hline Hypothesis & $\mathrm{OVH}$ & $\mathrm{MDH}$ & $\mathrm{MCCH}$ \\
\hline Type of Acquisition & FM & FM & TO \\
\hline$O_{i t}$ & $\begin{array}{l}0.005 \\
(1.48)\end{array}$ & & \\
\hline$V S_{i t}$ & $\begin{array}{c}-2.6^{*} 10^{-6} \\
(0.43)\end{array}$ & & \\
\hline$V S_{i t} * O_{i t}$ & $\begin{array}{c}1.2 * 10^{-6} \\
(0.70)\end{array}$ & & \\
\hline$q_{i t-1}$ & & $\begin{array}{c}-0.0013 \\
(3.46)\end{array}$ & $\begin{array}{l}-0.0021 \\
(5.88)\end{array}$ \\
\hline$C F_{i t}$ & & $\begin{array}{c}-0.0006 \\
(2.25)\end{array}$ & $\begin{array}{c}0.0042 \\
(4.54)\end{array}$ \\
\hline$K_{i t-1}$ & & $\begin{array}{c}-2.5^{*} 10^{-7} \\
(2.87)\end{array}$ & $\begin{array}{c}-6.9 * 10^{-8} \\
(0.90)\end{array}$ \\
\hline$L_{i t-1}$ & & $\begin{array}{l}0.0021 \\
(0.82)\end{array}$ & $\begin{array}{c}-0.0017 \\
(1.00)\end{array}$ \\
\hline $\mathrm{N}$ & 29642 & 85475 & 84209 \\
\hline Pseudo $\bar{R}^{2}$ & 0.008 & 0.012 & 0.026 \\
\hline $\begin{array}{l}\text { Consistent with } \\
\text { Hypothesis }\end{array}$ & No & Yes & Yes \\
\hline
\end{tabular}

Note: Dependent variable in columns 1 and 2 is a one for a firm if it is acquired in a friendly merger, zero otherwise. The dependent variable in column 3 is one if it is acquired in a tender offer, zero otherwise. $V S_{i t}$ is the product of the market value of a firm's equity times the fraction of the firm's outstanding stock held by insiders. The ownership data come from the Compact Disclosure database which is based on the Securities and Exchange Commission's corporate proxy statement. tstatistics are below coefficients. 
Table 6: The Returns to Acquiring Firms

\begin{tabular}{|c|c|c|c|c|c|c|c|c|c|c|}
\hline \multirow{2}{*}{ Window } & \multirow{2}{*}{$\begin{array}{l}\text { Period of } \\
\text { Acquisition }\end{array}$} & \multicolumn{3}{|c|}{ Friendly Mergers } & \multicolumn{3}{|c|}{ Tender Offers } & \multicolumn{3}{|c|}{ All Acquisitions } \\
\hline & & $\mathrm{N}$ & Mean & Median & $\mathrm{N}$ & Mean & Median & $\mathrm{N}$ & Mean & Median \\
\hline \multirow[t]{3}{*}{ Month of Acquisition } & Non-Wave & 1624 & $\begin{array}{l}0.021 \\
(0.09)\end{array}$ & -0.32 & 180 & $\begin{array}{c}0.92 \\
(1.39)\end{array}$ & -0.00 & 1804 & $\begin{array}{c}0.11 \\
(0.21)\end{array}$ & -0.29 \\
\hline & Wave & 1396 & $\begin{array}{c}0.37 \\
(1.42)\end{array}$ & 0.00 & 165 & $\begin{array}{c}2.23 \\
(2.56)\end{array}$ & 1.01 & 1561 & $\begin{array}{c}0.56 \\
(0.25)\end{array}$ & 0.13 \\
\hline & Difference & & $\begin{array}{l}-0.35 \\
(1.00)\end{array}$ & -0.32 & & $\begin{array}{l}-1.31 \\
(1.09)\end{array}$ & -1.01 & & $\begin{array}{l}-0.45 \\
(0.33)\end{array}$ & -0.42 \\
\hline \multirow[t]{3}{*}{$\begin{array}{c}\text { One Year after } \\
\text { Acquisition }\end{array}$} & Non-Wave & 1645 & $\begin{array}{l}-5.21 \\
(5.85)\end{array}$ & -8.43 & 184 & $\begin{array}{l}-2.78 \\
(2.61)\end{array}$ & -6.09 & 1829 & $\begin{array}{l}-4.97 \\
(0.84)\end{array}$ & -8.31 \\
\hline & Wave & 1524 & $\begin{array}{l}-7.95 \\
(7.36)\end{array}$ & -10.83 & 171 & $\begin{array}{l}-10.88 \\
(3.05)\end{array}$ & -12.43 & 1695 & $\begin{array}{l}-8.24 \\
(1.02)\end{array}$ & -10.97 \\
\hline & Difference & & $\begin{array}{l}2.73^{\mathrm{b}} \\
(1.95)\end{array}$ & $2.40^{\mathrm{a}}$ & & $\begin{array}{l}8.09^{b} \\
(4.00)\end{array}$ & $6.34^{\mathrm{b}}$ & & $\begin{array}{l}3.27^{\mathrm{b}} \\
(1.32)\end{array}$ & $2.66^{a}$ \\
\hline \multirow[t]{3}{*}{$\begin{array}{l}\text { Two Years after } \\
\text { Acquisition }\end{array}$} & Non-Wave & 1636 & $\begin{array}{l}-15.37 \\
(10.18)\end{array}$ & -22.17 & 183 & $\begin{array}{l}-2.63 \\
(4.73)\end{array}$ & -13.98 & 1819 & $\begin{array}{l}-14.09 \\
(1.44)\end{array}$ & -21.18 \\
\hline & Wave & 1513 & $\begin{array}{l}-20.75 \\
(12.35)\end{array}$ & -27.11 & 169 & $\begin{array}{l}-31.19 \\
(4.42)\end{array}$ & -37.36 & 1682 & $\begin{array}{l}-21.80 \\
(1.58)\end{array}$ & -28.35 \\
\hline & Difference & & $\begin{array}{l}5.37^{\mathrm{b}} \\
(2.39)\end{array}$ & $4.94^{\mathrm{a}}$ & & $\begin{array}{l}28.55^{a} \\
(6.50)\end{array}$ & $23.38^{\mathrm{a}}$ & & $\begin{array}{l}7.70^{\mathrm{a}} \\
(2.13)\end{array}$ & $7.17^{\mathrm{a}}$ \\
\hline \multirow[t]{3}{*}{$\begin{array}{l}\text { Three Years after } \\
\text { Acquisition }\end{array}$} & Non-Wave & 1625 & $\begin{array}{c}-23.38 \\
(11.24)\end{array}$ & -34.63 & 183 & $\begin{array}{c}-12.09 \\
(6.37)\end{array}$ & -23.82 & 1808 & $\begin{array}{l}-22.23 \\
(1.98)\end{array}$ & -33.47 \\
\hline & Wave & 1480 & $\begin{array}{l}-31.20 \\
(13.93)\end{array}$ & -42.62 & 167 & $\begin{array}{l}-45.85 \\
(6.14)\end{array}$ & -58.55 & 1647 & $\begin{array}{l}-32.68 \\
(2.11)\end{array}$ & -44.58 \\
\hline & Difference & & $\begin{array}{l}7.81^{\mathrm{a}} \\
(2.55)\end{array}$ & $7.99^{\mathrm{a}}$ & & $\begin{array}{l}33.75^{\mathrm{a}} \\
(8.89)\end{array}$ & $34.73^{\mathrm{a}}$ & & $\begin{array}{l}10.45^{\mathrm{a}} \\
(2.89)\end{array}$ & $11.11^{\mathrm{a}}$ \\
\hline
\end{tabular}

Note: The wave period includes six years from 1995 to 2000 . a and b indicate significant differences at $1 \%$ and $5 \%$ level, respectively. The median test is the Wilcoxon Ranksum test. t-statistics are in parentheses. 
Table 7: Overvaluation and Returns to Acquiring and Non-merging Firms

\begin{tabular}{|c|c|c|c|c|c|c|c|c|c|c|}
\hline Equation & Period & Sample & Intercept & $O_{t-1}$ & $d O_{i t-1}$ & Size & $\mathbf{N}$ & $\bar{R}^{2}$ & $\begin{array}{c}\text { Predicted Return } \\
\text { at Mean Size and } \\
O_{t-1}=d O_{i t-1}=0\end{array}$ & $\begin{array}{c}\text { Predicted } \\
\text { Return at } \\
\text { Means } \\
\end{array}$ \\
\hline 1 & Whole Period & Non-merging & $\begin{array}{c}0.845 \\
(18.63)\end{array}$ & $\begin{array}{l}-0.746 \\
(11.44)\end{array}$ & $\begin{array}{l}-0.035 \\
(4.02)\end{array}$ & $\begin{array}{l}0.000 \\
(0.04)\end{array}$ & 10015 & 0.014 & 0.846 & 0.536 \\
\hline 2 & Non-Wave & Non-merging & $\begin{array}{l}0.806 \\
(15.83\end{array}$ & $\begin{array}{l}-0.421 \\
(5.25)\end{array}$ & $\begin{array}{l}-0.056 \\
(5.07)\end{array}$ & $\begin{array}{l}-0.009 \\
(1.25)\end{array}$ & 8258 & 0.006 & 0.761 & 0.608 \\
\hline 3 & Wave & Non-merging & $\begin{array}{l}0.598 \\
(3.80)\end{array}$ & $\begin{array}{l}-0.942 \\
(3.99)\end{array}$ & $\begin{array}{l}-0.005 \\
(0.37)\end{array}$ & $\begin{array}{l}0.040 \\
(3.02)\end{array}$ & 1757 & 0.012 & 0.799 & 0.240 \\
\hline 4 & Whole Period & Friendly Mergers & $\begin{array}{l}-0.005 \\
(0.07)\end{array}$ & $\begin{array}{l}-0.333 \\
(2.91)\end{array}$ & $\begin{array}{l}-0.060 \\
(3.49)\end{array}$ & $\begin{array}{l}-0.015 \\
(1.52)\end{array}$ & 2029 & 0.010 & -0.104 & -0.274 \\
\hline 5 & Non-Wave & Friendly Mergers & $\begin{array}{l}-0.076 \\
(0.68)\end{array}$ & $\begin{array}{l}-0.158 \\
(1.02)\end{array}$ & $\begin{array}{l}-0.098 \\
(3.76)\end{array}$ & $\begin{array}{l}-0.015 \\
(1.15)\end{array}$ & 1114 & 0.011 & -0.173 & -0.238 \\
\hline 6 & Wave & Friendly Mergers & $\begin{array}{l}0.503 \\
(2.35)\end{array}$ & $\begin{array}{l}-1.098 \\
(3.41)\end{array}$ & $\begin{array}{l}-0.015 \\
(0.59)\end{array}$ & $\begin{array}{l}-0.019 \\
(1.21)\end{array}$ & 915 & 0.012 & 0.373 & -0.282 \\
\hline
\end{tabular}

Notes: The dependent variable is the return over a 36-month window. $O_{t-1}$ is the annual mean of the market wide overvaluation. $d O_{i t-1}$ is the deviation of firm i's overvaluation from $O_{t-1}$. Size is measured by the natural logarithm of total assets. The wave period includes six years from 1995 to 2000 . tstatistics are under the coefficients. 


\section{Notes:}

${ }^{1}$ The number of mergers is divided by population to control for the changing size of the economy. Although there has been some controversy over whether what look like waves in mergers are in fact waves, work by Golbe and White (1993) and Linn and Zhu (1997) for the United States, and Resende (1999) for the United Kingdom appears to have established rather firmly that mergers have come in waves.

${ }^{2}$ Ralph Nelson $(1959,1966)$ was the first to document the link between merger activity and share prices, and numerous subsequent studies have confirmed this finding. See, for example, Melicher, Ledolter and D'Antonio (1983), Geroski (1984) for the US, and Geroski (1984) and Clarke and Ioannidis (1996) for the UK.

${ }^{3}$ For surveys of this literature, see Steiner (1975), Scherer and Ross (1990, pp. 153-173), Mueller (2003, ch. 8), Weston, Chung and Hoag (1990).

${ }^{4}$ For a list of these 48 industries, see the appendix in Fama and French (1997).

${ }^{5}$ See Andrade and Stafford (1999), and Erard and Schaller (2002).

${ }^{6}$ These conceptual differences in applying the $q$-theory to mergers help explain why Andrade and Stafford (1999) find the cross-sectional patterns of investments in capital equipment and mergers to be quite dissimilar. Erard and Schaller (2002), on the other hand, claim that they are similar forms of investment.

7 See, for example, Chappell and Cheng (1984), Andrade and Stafford (1999), and Jovanovic and Rousseau (2002).

8 Since the ratio of the market value of a firm to the book value of its assets is used in several studies testing hypotheses about the determinants of mergers, we also use it here, and define and test the $q$-theory using this ratio. Past research reveals a high correlation between the two variables (Perfect and Wiles, 1994).

${ }^{9}$ We report averages for market value/total assets and deal value/total assets ratios for which we have data. Thus the number of firms in each column for any given year is not identical, although the overlap is substantial.

${ }^{10}$ Rhodes-Kropf and Viswanathan (2003, hereafter RKV) have presented a somewhat different version of the $\mathrm{OH}$. Since S\&V were the first to formulate the theory, we concentrate on their version but come back to discuss RKV's version along with the empirical results.

${ }^{11}$ We estimate $\alpha$ s for the years 1981-1994 when the S\&P P/E was near its long run average of $15 . \quad$ The 48 estimates of $\alpha$ were quite reasonable ranging between 3.36 and 17.45 with a mean of 9.40 .

${ }^{12}$ Schwert (2000) considers unnegotiated tender offers as a measure of the hostility of US deals. He also argues that bidders are more likely to be perceived as hostile when they use tender offers rather than merger proposals.

${ }^{13}$ Our measure for insider ownership is defined as the total number of shares held in aggregate by all officers and directors divided by the number of shares outstanding provided by the Compact Disclosure (CD) database. The sole source of ownership data used by CD is the Securities and Exchange Commission's corporate proxy statement.

${ }^{14}$ For recent evidence linking managerial income to growth through mergers, see Khorana and Zenner (1998).

${ }^{15}$ A further justification for including $q$ in the managers' utility function would be that managers own shares in the firm.

${ }^{16}$ There are many "shocks" leading to industry merger waves in the past that are very difficult to reconcile with the neoclassical theory. During the "60s merger wave, for example, the tobacco industry went through a wave of diversification mergers. The shock leading to this wave was a report of the US Surgeon General linking smoking to cancer and other diseases. Anticipated internal growth in the industry fell, and managers of the tobacco companies chose to substitute external for internal growth. Why a demonstration of the ill effects of smoking would create synergies between cigarette firms and razor, soft drinks and dog food companies is unclear. In the ' $70 \mathrm{~s}$ a wave of diversification mergers took place in the petroleum industry. The shock causing these was the OPEC oil price increases, which generated billions of dollars of profits for the major oil firms. Again the link between oil price increases and synergies from diversification is not readily apparent, nor was it apparent to the capital market. In the ' 80 s many oil companies had market values substantially below the known value of their oil reserves, and the oil companies became popular targets of corporate raiders. Fortune featured several of the petroleum company mergers in its list of the "worst mergers of the decade" (Fisher, 1984).

${ }^{17}$ See, Grabowski and Mueller (1972), Vogt (1994), Hay and Liu (1998), and Gugler, Mueller and Yurtoglu 
(2004).

${ }^{18}$ To our knowledge Schwartz (1984) is the only study testing the MDH for mergers. He does not link his results to merger waves, however.

${ }^{19}$ See Gugler, Mueller and Yurtoglu (2004).

${ }^{20}$ Several studies report higher premia for tender offers. The summary table of Jensen and Ruback (1985) shows that targets in successful tender offers enjoy a 30 percent positive return compared to 20 percent premium to targets in successful mergers. Schwert (1996) reports a premium of 20.1 percent for targets in tender offers and 4.9 percent for targets in mergers for a sample of 1814 mergers or tender offers from 1975 to 1991.

${ }^{21}$ For evidence establishing an inverse relationship between the gains to target and the gains to bidders, see Mueller and Sirower (2003).

${ }^{22}$ This amount excludes any fees and expenses. If a company undertakes more than one acquisition in a year, we use the total amount spent in all of these transactions.

${ }^{23}$ We obtain balance sheet, income statement and market value data from Compustat. A complete list of variable definitions along with Compustat item numbers is available form the authors upon request.

${ }^{24}$ Dong et al. (2002) and RKRV also obtain quite different results for friendly mergers and tender offers in their tests of the OVH.

${ }^{25}$ RKRV's version of the OVH emphasizes the willingness of the market to accept the overvalued shares of the acquirers.

${ }^{26}$ Empirical support for the OVH has been presented in recent papers by Dong et al. (2002), Ang and Cheng (2003), and RKRV. The tests of Dong et al. focus mainly on the choice of payment in mergers, and the pattern of post merger returns. Both Ang and Cheng and RKRV find a positive relationship between the likelihood that a firm becomes an acquirer and measures of overvaluation. Both studies include time dummies in their logit equations, however, which conceal the importance of the average overvaluation of the market in explaining merger activity.

${ }^{27}$ Ang and Cheng (2003, Table 3) include size in their logit regression to predict the identities of acquirers, although they offer a different justification for it. It is by far the most significant variable in the equation.

${ }^{28}$ Although Marris $(1963,1964)$ was arguably the first to formulate the hypothesis, the expression "market-forcorporate-control" was coined by Manne (1965). Jensen and Ruback (1983) survey several studies, which claim to support the hypothesis.

${ }^{29}$ Leverage is the ratio of total debt (short-term and long-term) to total assets.

${ }^{30}$ Ang and Cheng (2003) also present evidence that the acquirers' shareholders do not suffer immediate losses when the mergers are announced.

${ }^{31}$ Dong et al. (2002) and Ang and Cheng (2003) both present evidence of lower post-merger returns for acquirers, which fit the OVH. Moeller, Schlingemann and Stulz (2005) also find that returns for mergers during the wave of the 1990s were significantly lower than for mergers before the wave, although there results differ from ours in that the losses occurred immediately upon the announcements.

${ }^{32} \mathrm{We}$ also conducted the tests for one- and two-year returns and obtained similar results. These are not reported in the interests of space.

${ }^{33}$ For surveys discussing this evidence and trying to solve the riddle, see Mueller $(1977,2003)$, Jensen and Ruback (1983), Caves (1989), Scherer and Ross (1990, pp. 167-174), and Agrawal and Jaffee (2000). 
Bücher des Forschungsschwerpunkts Markt und politische Ökonomie

Books of the Research Area Markets and Political Economy

Pablo Beramendi

Decentralization and Income Inequality

2003, Madrid: Juan March Institute

Thomas Cusack

A National Challenge at the Local Level: Citizens, Elites and Institutions in Reunified Germany

2003, Ashgate

Sebastian Kessing

Essays on Employment Protection

2003, Freie Universität Berlin

http://www.diss.fu-berlin.de/2003/202

Daniel Krähmer

On Learning and Information in Markets and

Organizations

2003, Shaker Verlag

Bob Hancké

Large Firms and Institutional Change. Industrial Renewal and Economic Restructuring in France 2002, Oxford University Press

Andreas Stephan

Essays on the Contribution of Public Infrastruc-

ture to Private: Production and its Political

Economy

2002, dissertation.de

Peter A. Hall, David Soskice (Eds.)

Varieties of Capitalism

2001, Oxford University Press

Hans Mewis

Essays on Herd Behavior and Strategic Delegation

2001, Shaker Verlag

Andreas Moerke

Organisationslernen über Netzwerke - Die

personellen Verflechtungen von Führungsgremien

japanischer Aktiengesellschaften

2001, Deutscher Universitäts-Verlag

Silke Neubauer

Multimarket Contact and Organizational Design

2001, Deutscher Universitäts-Verlag

Lars-Hendrik Röller, Christian Wey (Eds.)

Die Soziale Marktwirtschaft in der neuen

Weltwirtschaft, WZB Jahrbuch 2001

2001, edition sigma

Michael Tröge

Competition in Credit Markets: A Theoretic

Analysis

2001, Deutscher Universitäts-Verlag

Torben Iversen, Jonas Pontusson, David Soskice

(Eds.)

Unions, Employers, and Central Banks

2000, Cambridge University Press
Tobias Miarka

Financial Intermediation and Deregulation:

A Critical Analysis of Japanese Bank-Firm-

Relationships

2000, Physica-Verlag

Rita Zobel

Beschäftigungsveränderungen und

organisationales Lernen in japanischen

Industriengesellschaften

2000, Humboldt-Universität zu Berlin

http://dochost.rz.hu-berlin.de/dissertationen/zobel-rita2000-06-19

Jos Jansen

Essays on Incentives in Regulation and Innovation 2000, Tilburg University

Ralph Siebert

Innovation, Research Joint Ventures, and

Multiproduct Competition

2000, Humboldt-Universität zu Berlin

http://dochost.rz.hu-berlin.de/dissertationen/siebert-

ralph-2000-03-23/

Damien J. Neven, Lars-Hendrik Röller (Eds.)

The Political Economy of Industrial Policy in

Europe and the Member States

2000, edition sigma

Jianping Yang

Bankbeziehungen deutscher Unternehmen:

Investitionsverhalten und Risikoanalyse

2000, Deutscher Universitäts-Verlag

Christoph Schenk

Cooperation between Competitors -

Subcontracting and the Influence of Information,

Production and Capacity on Market Structure and

Competition

1999, Humboldt-Universität zu Berlin

http://dochost.rz.hu-berlin.de/dissertationen/schenkchristoph-1999-11-16

Horst Albach, Ulrike Görtzen, Rita Zobel (Eds.)

Information Processing as a Competitive

Advantage of Japanese Firms

1999, edition sigma

Dieter Köster

Wettbewerb in Netzproduktmärkten

1999, Deutscher Universitäts-Verlag

Christian Wey

Marktorganisation durch Standardisierung: Ein

Beitrag zur Neuen Institutionenökonomik des

Marktes

1999, edition sigma 
Lutz Engelhardt

Philipp Rehm

Sigurt Vitols Lutz Engelhardt

Sebastian G. Kessing

Kai A. Konrad

Kai A. Konrad Amedeo Spadaro

Joseph A. Clougherty

Talat Mahmood

Sara Geerdes Klaus Schömann

Johannes Münster

Albert Banal-Estañol Jo Seldeslachts

Kai A. Konrad

Johannes Münster

Oz Shy

Kai A. Konrad Stergios Skaperdas

Kai A. Konrad

Dan Kovenock

Thomas Cusack

Torben Iversen

Philipp Rehm

Tomaso Duso

Klaus Gugler

Burcin Yurtoglu

Dan Kovenock

Brian Roberson

Sebastian G. Kessing

Kai A. Konrad

Christos Kotsogiannis
Geschäftsmodelle und nationale Institutionen: Ein

SP || $2005-01$ Vergleich britischer und deutscher Neuemissionen aus der IT-Service - und Softwareindustrie 1996 2002

Citizen Support for the Welfare State: Determinants of Preferences for Income Redistribution

National Institutions and High Tech Industries:

A Varieties of Capitalism Perspective on the Failure of Germany's "Neuer Markt"

Union Strategy and Optimal Income

Taxation

Education, Redistributive Taxation, and

Confidence

The International Drivers of Domestic Airline

Mergers in Twenty Nations: Integrating Industrial

Organization and International Business

Unmet Labour Demand In Europe - Chances for

Immigrants?

Simultaneous Inter- and Intra-Group Conflicts

Merger Failures

SP || $2005-08$

SP || 2005- 09

Silent Interests and All-Pay Auctions

SP || $2005-10$

Lobbying Contests with Endogenous Policy

Proposals

SP || $2005-11$

SP || $2005-12$

Conversion: Theory and Calibration

Succession Rules and Leadership Rents

SP || $2005-13$

Equilibrium and Efficiency in the Tug-of-War

SP || $2005-14$

Risks at Work: The Demand and Supply Sides of Government Redistribution

SP || $2005-15$

EU Merger Remedies: A Preliminary Empirical

Assessment

SP || $2005-16$

Electoral Poaching and Party Identification

SP || $2005-17$

Federal Tax Autonomy and the Limits of

Cooperation 
Jonathan Beck Michał Grajek

Christian Wey

Ela Glowicka

Richard Deeg
Hypermarket Competition and the Diffusion of Retail Checkout Barcode Scanning

SP || $2005-19$

SP || $2005-20$ Approach

Complementarity and Institutional Change: How Useful a Concept?
SP || $2005-21$ 


\section{DISCUSSION PAPERS 2006}

Klaus Gugler The Determinants of Merger Waves SP || $2006-01$

Dennis C. Müller

B. Burçin Yurtoglu 
Bei Ihren Bestellungen von WZB-Papers schicken

Sie bitte unbedingt einen an Sie adressierten Auf-

kleber mit sowie je paper eine Briefmarke im Wert

von 0,51 Euro oder einen "Coupon Reponse Inter-

national " (für Besteller aus dem Ausland)
Please send a self addressed label and postage stamps in the amount of 0.51 Euro or a "CouponReponse International" (if you are ordering from outside Germany) for each WZB-paper requested

Absender I Return Address:

Wissenschaftszentrum Berlin

für Sozialforschung

Presse- und informationsreferat

Reichpietschufer 50

D-10785 Berlin-Tiergarten

Hiermit bestelle ich folgende(s)

Discussion paper(s):

Please send me the following Discussion paper(s):

Bestell-Nr. I Order no.

Autor/in, Kurztitel /Author(s) / Title(s) in brief 